Article

\title{
Changes in Ammonia-Oxidizing Archaea and Bacterial Communities and Soil Nitrogen Dynamics in Response to Long-Term Nitrogen Fertilization
}

\author{
Aixia Xu ${ }^{1,2}$, Lingling $\mathrm{Li}^{1,2, * \mathbb{C}}$, Junhong Xie ${ }^{1,2}$, Subramaniam Gopalakrishnan ${ }^{3} \mathbb{D}^{\mathbb{D}}$, Renzhi Zhang ${ }^{1,4}$, \\ Zhuzhu Luo ${ }^{1,4}$, Liqun Cai ${ }^{1,4}$, Chang Liu ${ }^{1}$, Linlin Wang ${ }^{1,2} \mathbb{D}$, Sumera Anwar ${ }^{5}$ and Yuji Jiang ${ }^{6, *(D)}$ \\ 1 State Key Laboratory of Aridland Crop Science, Gansu Agricultural University, Lanzhou 730070, China; \\ xuax@gsau.edu.cn (A.X.); xiejh@gsau.edu.cn (J.X.); zhangrz@gsau.edu.cn (R.Z.); luozz@gsau.edu.cn (Z.L.); \\ cailq@gsau.edu.cn (L.C.); liuc@gsau.edu.cn (C.L.); wangll@gsau.edu.cn (L.W.) \\ 2 College of Agronomy, Gansu Agricultural University, Lanzhou 730070, China \\ 3 International Crops Research Institute for the Semi-Arid Tropics (ICRISAT), Patancheru, \\ Hyderabad 502324, Telangana, India; s.gopalakrishnan@cgiar.org \\ 4 College of Resource and Environment, Gansu Agricultural University, Lanzhou 730070, China \\ 5 Institute of Molecular Biology and Biotechnology, The University of Lahore, Lahore 54000, Pakistan; \\ anwer_sumera@yahoo.com \\ 6 State Key Laboratory of Soil and Sustainable Agriculture, Institute of Soil Science, \\ Chinese Academy of Sciences, Nanjing 210008, China \\ * Correspondence: lill@gsau.edu.cn (L.L.); yjjiang@issas.ac.cn (Y.J.)
}

check for updates

Citation: Xu, A.; Li, L.; Xie, J.; Gopalakrishnan, S.; Zhang, R.; Luo, Z.; Cai, L.; Liu, C.; Wang, L.; Anwar, S.; et al. Changes in Ammonia-Oxidizing Archaea and Bacterial Communities and Soil Nitrogen Dynamics in Response to Long-Term Nitrogen Fertilization. Int J. Environ. Res. Public Health 2022, 19, 2732. https://doi.org/10.3390/ ijerph19052732

Academic Editor: Nikolay Bojkov Vassilev

Received: 11 January 2022 Accepted: 24 February 2022 Published: 26 February 2022

Publisher's Note: MDPI stays neutral with regard to jurisdictional claims in published maps and institutional affiliations.

Copyright: (c) 2022 by the authors Licensee MDPI, Basel, Switzerland. This article is an open access article distributed under the terms and conditions of the Creative Commons Attribution (CC BY) license (https:// creativecommons.org/licenses/by/ $4.0 /)$.

\begin{abstract}
Ammonia oxidizing archaea (AOA) and bacteria (AOB) mediate a crucial step in nitrogen (N) metabolism. The effect of $\mathrm{N}$ fertilizer rates on AOA and AOB communities is less studied in the wheat-fallow system from semi-arid areas. Based on a 17-year wheat field experiment, we explored the effect of five $\mathrm{N}$ fertilizer rates $\left(0,52.5,105,157.5\right.$, and $\left.210 \mathrm{~kg} \mathrm{ha}^{-1} \mathrm{yr}^{-1}\right)$ on the AOA and AOB community composition. This study showed that the grain yield of wheat reached the maximum at $105 \mathrm{~kg} \mathrm{~N} \mathrm{ha}^{-1}$ (49\% higher than control), and no further significant increase was observed at higher $\mathrm{N}$ rates. With the increase of $\mathrm{N}, \mathrm{AOA}$ abundance decreased in a regular trend from $4.88 \times 10^{7}$ to $1.05 \times 10^{7}$ copies $^{-1}$ dry soil, while AOB abundance increased from $3.63 \times 10^{7}$ up to a maximum of $8.24 \times 10^{7}$ copies $\mathrm{g}^{-1}$ dry soil with the $\mathrm{N} 105$ treatment $\left(105 \mathrm{~kg} \mathrm{~N} \mathrm{ha}^{-1} \mathrm{yr}^{-1}\right)$. Application rates of $\mathrm{N}$ fertilizer had a more significant impact on the AOB diversity than on AOA diversity, and the highest AOB diversity was found under the N105 treatment in this weak alkaline soil. The predominant phyla of AOA and AOB were Thaumarchaeota and Proteobacteria, respectively, and higher N treatment (N210) resulted in a significant decrease in the relative abundance of genus Nitrosospira. In addition, $\mathrm{AOA}$ and $\mathrm{AOB}$ communities were significantly associated with grain yield of wheat, soil potential nitrification activity (PNA), and some soil physicochemical parameters such as $\mathrm{pH}, \mathrm{NH}_{4}-\mathrm{N}$, and $\mathrm{NO}_{3}-\mathrm{N}$. Among them, soil moisture was the most influential edaphic factor for structuring the AOA community and $\mathrm{NH}_{4}-\mathrm{N}$ for the AOB community. Overall, $105 \mathrm{~kg} \mathrm{~N}^{-1} \mathrm{yr}^{-1}$ was optimum for the $\mathrm{AOB}$ community and wheat yield in the semi-arid area.
\end{abstract}

Keywords: ammonia-oxidizing bacteria (AOB); ammonia-oxidizing archaea (AOA); nitrogen use efficiency (NUE); soil properties

\section{Introduction}

Nitrification is the most crucial step in the biogeochemical nitrogen $(\mathrm{N})$ cycle in which $\mathrm{NH}_{3}$ is oxidized to $\mathrm{NO}_{2}{ }^{-}$and then to $\mathrm{NO}_{3}{ }^{-}$[1-3]. The nitrification process regulates the absorption and availability of $\mathrm{N}$ to crops in the soil ecosystem [4,5] and may also cause the loss of $\mathrm{N}$ because leaching of $\mathrm{NO}_{3}{ }^{-}$is much easier than $\mathrm{NH}_{3}$ [6]. Ammonia oxidizing archaea $(\mathrm{AOA})$ and bacteria $(\mathrm{AOB})$ mediate a very critical step in nitrogen $(\mathrm{N})$ metabolism $[7,8]$. Both AOA and AOB contain the gene encoding the ammonia monooxygenase amo $A$, which 
has the catalytic ability to oxidize ammonia to hydroxylamine, which can be used as a marker for evaluating AOA and AOB abundances [9]. However, AOA and AOB communities' response to environmental drivers is still not completely understood $[10,11]$.

Nitrogen is the main element and a limiting nutrient for sustainable agricultural production $[12,13]$. The application of chemical $\mathrm{N}$ fertilizers, such as urea or ammonium compounds, is the main source of $\mathrm{N}$ in the agricultural system worldwide [14]. Long-term $\mathrm{N}$ application not only drives the loss of biodiversity in the agricultural ecosystem [15-17] but also usually regulates the continuous increase of soil potential nitrification activity (PNA) [18]. The change of PNA is considered to be closely related to soil $\mathrm{pH}$ and the community of ammonia oxidizers [19]. Fertilization affects the diversity and structure of $\mathrm{AOB}$ and AOA communities, however, there are still few studies on long-term inorganic $\mathrm{N}$ fertilization affecting ammonia oxidation in agricultural soils [20]. More than one-third of the world's production and consumption of $\mathrm{N}$ fertilizer is in China [21]. The extensive input of ammonium fertilizers (such as urea) has been reported to selectively stimulate the AOA or AOB abundance in the agricultural field [19], and in turn, microorganism-mediated nitrification ultimately leads to a reduction of nitrogen use efficiency (NUE) [22,23]. Moreover, excessive $\mathrm{N}$ fertilizer application not only increases the risk of nitrate $\left(\mathrm{NO}_{3}-\mathrm{N}\right)$ leaching and runoff loss [24,25], and loss of $\mathrm{N}_{2} \mathrm{O}$ or $\mathrm{N}_{2}$ due to denitrification and ammonia oxidation [26], but also leads to severe pollution [27] and greenhouse effect [28,29], which have been major environmental problems in some regions of Europe, the United States, and China [30-32]. Therefore, most countries in the EU have taken measures to limit the rate of $\mathrm{N}$ application $[33,34]$. Thus, there is an urgent need to understand the response of ammonia oxidizers to $\mathrm{N}$ fertilizer applications and to predict the effectiveness and safety of $\mathrm{N}$ fertilizer applications [26,35].

AOA and AOB coexist in various soil types, coping with environmental disturbances and resource utilization in different ways [11,36]. Some studies have confirmed that the AOA community dominates agricultural soils [37-39] and is a primary driving force of nitrification [40,41]. However, some studies have also shown that although AOA has an absolute advantage in quantity, AOB has a dominant position in function [42,43]. In diverse soil ecosystems, the ratio of soil AOA to AOB in semiarid ecosystems is from 17 to 1600 [6]. Studies have shown that soil $\mathrm{N}$ availability and $\mathrm{pH}$ are key factors in constructing AOA and AOB communities, AOA prefers less ammonia and acidic conditions, while AOB prefers nitrogen-rich alkaline conditions [19,42]. In addition, temperature [44] and $\mathrm{O}_{2}$ [45] are also effective factors affecting AOA and AOB communities. The oxidation of ammonia is traditionally thought to be carried out by $A O B$, so N-based fertilization may be a primary driver for AOB [46]. However, recent studies have shown that AOA are also ammonia-oxidizing [47].

Long-term application of chemical $\mathrm{N}$ fertilizer will cause changes in soil physicochemical parameters [48]. However, there is still a lack of evidence on how long-term different $\mathrm{N}$ gradients affect the soil properties, and thus the activity, composition, and AOA and $\mathrm{AOB}$ abundance in semi-arid areas. This study hypothesized that $\mathrm{N}$ fertilization affects soil parameters and $\mathrm{AOA}$ and $\mathrm{AOB}$ abundance, thereby influencing crop yield and $\mathrm{N}$ utilization efficiency. Therefore, this study selected a 17-year wheat field experiment with different rates of $\mathrm{N}$ application, assessed the abundance of AOA and AOB communities by real-time quantitative PCR (qPCR), and assessed the community composition and structure of AOA and AOB by Illumina sequencing. The purpose was to explore: (i) the effect of $\mathrm{N}$ fertilization on the abundance of soil ammonia-oxidizing archaea (AOA) and ammonia-oxidizing bacteria ( $\mathrm{AOB}$ ) communities; (ii) the effect of $\mathrm{N}$ fertilization on the diversity and community composition of AOA and AOB communities; and (iii) the influence relationship and mechanism among $\mathrm{N}$ fertilization, soil physicochemical parameters, PNA, wheat yield, and NUE. Our research will deepen understanding soil factors in driving AOA and AOB diversity, $\mathrm{N}$ utilization efficiency, and $\mathrm{N}$ management in semiarid soil agricultural production. 


\section{Materials and Methods}

\subsection{Site Description and Experimental Design}

The field site was located at the Dingxi Experimental Station of Gansu Agricultural University, Dingxi, Gansu Province, China (35²8 $8^{\prime}$ N, $104^{\circ} 44^{\prime}$ E, elevation $1971 \mathrm{~m}$ a.s.1.). The soil for the field trials was Calcaric Cambisoll [49], locally called Huangmian [50].

Nitrogen fertilizer (urea) was applied every year from 2003 to 2019 before spring wheat sowing. The five $\mathrm{N}$ rates, i.e., N0 (non-N-fertilized control), N52.5 (52.5 kg N ha $\left.{ }^{-1}\right)$, N105 (105.0 kg N ha $\left.{ }^{-1}\right), \mathrm{N} 157.5\left(157.5 \mathrm{~kg} \mathrm{~N}^{-1}\right)$, and N210 (210.0 $\left.\mathrm{kg} \mathrm{N} \mathrm{ha}^{-1}\right)$, and three replications of each $\mathrm{N}$ were arranged in a randomized block design. The area of each test plot was $10 \mathrm{~m} \times 3 \mathrm{~m}$. The calcium superphosphate $\left(105 \mathrm{~kg} \mathrm{P}_{2} \mathrm{O}_{5} \mathrm{ha}^{-1}\right)$ was applied to all plots. Before sowing, the fertilizers were spread evenly over the entire cultivated area and incorporated into the $0-20 \mathrm{~cm}$ soil layer with a rotary tiller. Spring wheat (Dingxi No. 38) was sown in mid-March at a row spacings of $20 \mathrm{~cm}$ and a sowing density of $187.5 \mathrm{~kg} \mathrm{ha}{ }^{-1}$. The basic physicochemical parameters of soil from 0-100 $\mathrm{cm}$ depth, recorded in 2003 were: $0.78 \mathrm{~g} \mathrm{~kg}^{-1}$ total $\mathrm{N}, 4.92 \mathrm{mg} \mathrm{kg}^{-1} \mathrm{NH}_{4}-\mathrm{N}, 27.12 \mathrm{mg} \mathrm{kg}^{-1} \mathrm{NO}_{3}-\mathrm{N}, 8.33 \mathrm{pH}$, $5.98 \mathrm{mg} \mathrm{kg}^{-1}$ available phosphorus, $1.80 \mathrm{~g} \mathrm{~kg}^{-1}$ total phosphorus, $18.37 \mathrm{~g} \mathrm{~kg}^{-1}$ total potassium, $201.43 \mathrm{mg} \mathrm{kg}^{-1}$ available potassium, $1.20 \mathrm{~g} \mathrm{~cm}^{-3}$ bulk density, and $12.27 \mathrm{~g} \mathrm{~kg}^{-1}$ organic matter. The field site's average daily minimum (January) and maximum (July) temperatures from 2003 to 2019 were $-22{ }^{\circ} \mathrm{C}$ and $38^{\circ} \mathrm{C}$, respectively, with $7.4{ }^{\circ} \mathrm{C}$ mean annual temperature, $390.7 \mathrm{~mm} \mathrm{yr}^{-1}$ mean annual precipitation, $1531 \mathrm{~mm}$ mean annual evaporation, and $5930 \mathrm{MJ} \mathrm{m}^{-2}$ mean annual radiation.

\subsection{Sampling and Physicochemical Analyses}

During the flowering stage of wheat in 2019, soil samples were collected from each plot using an auger. Each sample was composed of 5 random cores of $0-20 \mathrm{~cm}$ soil layers, mixed and separated into two sub-samples. One sub-sample was used to determine physicochemical parameters analyses, and the second subsample was used for molecular analyses.

Soil total nitrogen (TN) was analyzed using the method of Semimicro-Kjeldahl digestion analyses [51], while $\mathrm{NH}_{4}-\mathrm{N}$ and $\mathrm{NO}_{3}-\mathrm{N}$ were analyzed using the method of spectrophotometry [52]. The soil $\mathrm{pH}$ was analyzed using a glass combination electrode in a suspension of soil and water (ratio 1:2.5) [53]. The available phosphorus and total phosphorus in the soil were measured using the molybdenum antimony colorimetric method [51] and soil moisture (SM) was measured using the drying method [54]. Soil potential nitrification activity (PNA) was analyzed using the method of chlorate inhibition [55].

\subsection{DNA Extraction and $q P C R$}

The total DNA was extracted using an EZNA ${ }^{\circledR}$ soil DNA kit (Omega, cat: M563502, CA, USA), and the quality of the extraction was checked by $1.2 \%$ agarose gel electrophoresis and then measured with a spectrophotometer (NanoDrop 2000, Thermo, New York, NY, USA) to quantify. Abundance of AOA and AOB were determined by the SYBR Green dye method real-time PCR experiment (mRNA) (absolute quantification PCR, AQ-PCR). All qPCR reactions were performed using a Q5 ${ }^{\circledR}$ High-Fidelity DNA Polymerase kit (M0491, Gene Biotechnology International Trade Co., Ltd., Shanghai, China) with TIB8600 PCR System. The primers for AOA gene abundance were Arch-amoA26F (5'-GACTACATMTTCTAYACWGAYTGGGC-3') and Arch-amoA417R (5' GGKGTCATRTATGGWGGYAAYGTTGG-3') [56], while primers for AOB gene abundance were F (5'-GGGGTTTCTACTGGTGGT-3') and R (5'-CCCCTCKGSAAAGCCTTCTTC$3^{\prime}$ ) [57]. The standard curve with known copy number was used as the standard curve, and the initial copy number of the unknown sample DNA was obtained by measuring the threshold cycle $(\mathrm{Ct})$ value of the unknown sample and combining with the standard curve. The gene copy numbers of $a m o A$ AOA and AOB were recorded as copies in one $g$ soil. The amplification efficiencies of AOA and AOB were $87.8 \%$ and $82.5 \%$, respectively, and $R^{2}$ values were 0.9993 and 0.9995 , respectively. The copy number $\left(X_{0}\right)$ was calculated as follows: 


$$
\mathrm{Ct}=-\mathrm{K} \log \mathrm{X}_{0}+\mathrm{b}
$$

\subsection{Illumina Miseq Sequencing and Bioinformatic Analysis}

The sequences of the PCR products were obtained using the Illumina MiSeq platform and the primers described above. The PCR amplified product was quantified with the Quant-iT PicoGreen dsDNA Assay Kit (Shanghai Yanhui Biotech. Co., Ltd., Shanghai, China) and a microplate reader (FLx800 BioTek). The qualified computer sequencing libraries were mixed in corresponding proportions according to the required sequencing amount and were denatured into single strands with $\mathrm{NaOH}$ for computer sequencing. The MiSeq Reagent Kit V3 (600 cycles, Shenzhen Hisian Biotechnology Co., Ltd., Shenzhen, China) reagent and MiSeq sequencer were used for the double-end measurement. The optimal sequencing insert range was kept as 200 to $450 \mathrm{bp}$ to limit the read length of MiSeq sequencing while ensuring sequencing quality. The sequence was denoised using the QIIME2 dada2 analysis, and the remaining were clustered into operational classification units (OTU) using the Vsearch software analysis and used for subsequent analysis.

After quality filtering using QIIME2, we obtained 611,587 amoA AOA and 321,422 amo A $\mathrm{AOB}$ sequences among 15 soil samples. The number of AOA sequences in each sample ranged from 29,767 to 69,464 , and the AOB ranged from 15,688 to 25,333 . The sequences of $\mathrm{AOA}$ and $\mathrm{AOB}$ were rarefied to 28,278 and 14,903 per sample, respectively.

\subsection{Statistical Analysis}

One-way ANOVA with Duncan testing was used to determine the significance of $\mathrm{N}$ rates on the wheat grain yield (GY), NUE, soil physicochemical parameters, the abundance of AOA, AOB, and alpha diversity. The correlations among soil physicochemical parameters, PNA, AOA, and AOB abundance were evaluated by Pearson's correlation coefficient analysis. The differences between the community structure of AOA and AOB under $\mathrm{N}$ fertilizer treatments were calculated using principal coordinate analysis (PCoA). Canoco 5.0 was used to analyze the relationships between soil physicochemical traits and $\mathrm{AOA}$ and $\mathrm{AOB}$ abundance. The relationship between soil environmental parameters and the structure of amo A AOA and amoA AOB was coordinated by Redundancy Analysis (RDA). Forward selection was conducted to test the significance of soil physicochemical parameters on the AOA and $\mathrm{AOB}$ community structure. The network was constructed from all soil samples taken together.

\section{Results}

\subsection{Soil Physicochemical Parameters, PNA, Yield of Wheats, and NUE}

The soil physicochemical properties were significantly altered after 17 years of different $\mathrm{N}$ fertilization rates (Table 1). The soil was weakly alkaline, and the $\mathrm{pH}$ was decreased from 8.99 to 8.67 (decrease by 2.04-3.58\%) with increasing fertilizer rates. A significant difference in soil $\mathrm{pH}$ was recorded between $\mathrm{N} 0$ and $\mathrm{N}$, and soil $\mathrm{pH}$ at $\mathrm{N} 52.5$ was significantly higher than that at $\mathrm{N} 157.5$ and $\mathrm{N} 210$. Soil $\mathrm{NH}_{4}-\mathrm{N}$ and $\mathrm{NO}_{3}-\mathrm{N}$ were increased by $0.91-55.20 \%$ and $25.62-175.85 \%$ by increasing $\mathrm{N}$ rates, respectively. Available phosphorus (AP) was significantly enhanced (23.29\%) by the application of $105 \mathrm{~kg} \mathrm{~N}^{-1}$ compared with no-N control. No significant difference in total phosphorus, total $\mathrm{N}$, and moisture contents was observed with $\mathrm{N}$ addition.

The rates of $\mathrm{N}$ fertilizer application significantly affected the potential nitrification activity (PNA) (Table 1). The PNA ranged from 1.22 to $2.32 \mathrm{mg} \mathrm{NO}_{3}-\mathrm{N} \mathrm{g}^{-1} \mathrm{~h}^{-1}$, and the highest PNA was obtained under the N105 treatment. In addition, under the N52.5, N105, N157.5, and N210 treatments, PNA was elevated by 38.52, 90.08, 43.16, and 46.78\% compared to N0 treatment, respectively. The grain yield of wheat (GY) was significantly influenced by the rates of $\mathrm{N}$ fertilizer, and up to the maximum under the N105 treatment (Table 1). The N-fertilizer treatments significantly increased the GY by $21-74 \%$. The NUE ranged from 13.61 to $19.64 \%$, and the N210 treatment had the lowest NUE. 
Table 1. Soil nutrients, potential nitrification activity, wheat grain yield, and nitrogen use efficiency as affected by nitrogen fertilizer treatments.

\begin{tabular}{|c|c|c|c|c|c|c|c|c|c|c|}
\hline Treatment & $\mathrm{pH}$ & $\begin{array}{c}\mathrm{TN} \\
\left(\mathrm{g} \mathrm{kg}^{-1}\right)\end{array}$ & $\begin{array}{c}\mathrm{NH}_{4}-\mathrm{N} \\
\left(\mathrm{mg} \mathrm{kg}^{-1}\right)\end{array}$ & $\begin{array}{c}\mathrm{NO}_{3}-\mathrm{N} \\
\left(\mathrm{mg} \mathrm{kg}^{-1}\right)\end{array}$ & $\begin{array}{c}\mathrm{TP} \\
\left(\mathrm{g} \mathrm{kg}^{-1}\right)\end{array}$ & $\begin{array}{c}\mathrm{AP} \\
\left(\mathrm{mg} \mathrm{kg}^{-1}\right)\end{array}$ & $\begin{array}{l}\text { SM } \\
(\%)\end{array}$ & $\begin{array}{c}\text { PNA } \\
\left(\mathrm{mg} \mathrm{NO}_{3}-\mathrm{N}\right. \\
\left.\mathrm{kg}^{-1} \mathrm{ha}^{-1}\right)\end{array}$ & $\begin{array}{c}\text { GY } \\
\left(\mathrm{kg} \mathrm{ha}^{-1}\right)\end{array}$ & $\begin{array}{l}\text { NUE } \\
(\%)\end{array}$ \\
\hline N0 & $8.99 \pm 0.04 a$ & $0.91 \pm 0.04 \mathrm{a}$ & $10.96 \pm 0.13 b$ & $12.92 \pm 0.10 \mathrm{e}$ & $0.74 \pm 0.03 a$ & $18.16 \pm 1.19 b$ & $12.13 \pm 0.75 a$ & $1.22 \pm 0.04 c$ & $2696.65 \pm 107.12 c$ & - \\
\hline N105 & $8.72 \pm 0.02 b c$ & $1.05 \pm 0.02 \mathrm{a}$ & $11.62 \pm 1.32 b$ & $21.42 \pm 0.52 c$ & $0.88 \pm 0.05 a$ & $22.39 \pm 0.17 a$ & $11.98 \pm 0.22 \mathrm{a}$ & $2.32 \pm 0.15 a$ & $4007.88 \pm 158.98 a$ & $19.07 \pm 0.56 a$ \\
\hline N157.5 & $8.67 \pm 0.01 c$ & $1.01 \pm 0.03 a$ & $16.47 \pm 0.21 \mathrm{a}$ & $30.07 \pm 0.56 b$ & $0.88 \pm 0.07 a$ & $19.84 \pm 0.57 b$ & $11.4 \pm 0.41 \mathrm{a}$ & $1.75 \pm 0.12 b$ & $4675.52 \pm 33.67 \mathrm{a}$ & $16.3 \pm 0.73 \mathrm{ab}$ \\
\hline N210 & $8.68 \pm 0.04 c$ & $0.96 \pm 0.01 \mathrm{a}$ & $17.01 \pm 0.32 \mathrm{a}$ & $35.64 \pm 0.35 a$ & $0.87 \pm 0.06 a$ & $20.15 \pm 0.69 b$ & $11.23 \pm 0.65 a$ & $1.79 \pm 0.14 b$ & $4209.77 \pm 156.71 a$ & $13.61 \pm 0.68 b$ \\
\hline $\begin{array}{l}\text { ANOVA } \\
p \text {-value }\end{array}$ & 0.002 & 0.410 & $<0.001$ & $<0.001$ & 0.417 & 0.032 & 0.647 & 0.001 & $<0.001$ & 0.042 \\
\hline
\end{tabular}

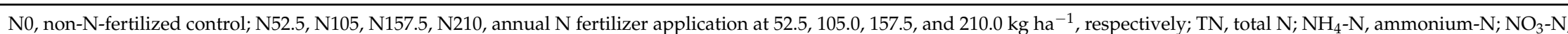
nitrate-N; TP, total phosphorus; AP, available phosphorus; SM, soil moisture; PNA, potential nitrification activity; GY, wheat grain yield; NUE, nitrogen use efficiency. Values are means of three replicates \pm standard error. Within a column, means followed by different letters are significantly different at $p<0.05$. 


\subsection{Community Abundances of $A O A$ and $A O B$}

The ammonia-oxidizing archaea (AOA) and bacterial (AOB) abundance were determined by quantifying gene copy number using quantitative PCR (Figure 1). With the increase of $\mathrm{N}, \mathrm{AOA}$ abundance was decreased in a regular trend from $4.88 \times 10^{7}$ to $1.05 \times 10^{7}$ copies $\mathrm{g}^{-1}$ dry soil, while AOB abundance increased from $3.63 \times 10^{7}$ up to a maximum of $8.24 \times 10^{7}$ copies $g^{-1}$ dry soil with the N105 treatment. Compared with the non-N control, the N52.5, N105, N157.5, and N210 treatments significantly increased the AOB community population by $50 \%, 127 \%, 116 \%$, and $79 \%$, while decreasing the AOA community population by $48 \%, 57 \%, 75 \%$, and $78 \%$, respectively. The ratios of AOA to $\mathrm{AOB}$ decreased with increasing $\mathrm{N}$ fertilizer rates, ranging from 1.34 to 0.16 .

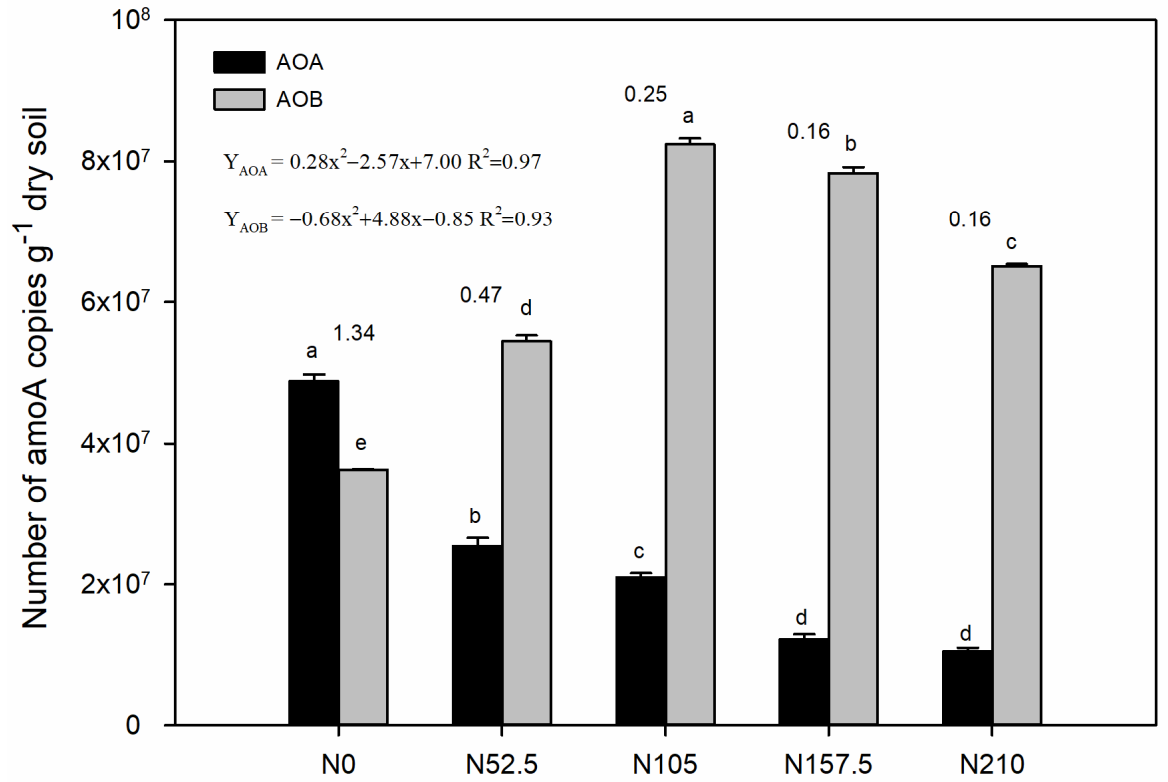

Figure 1. Abundances of ammonium-oxidizing archaea (AOA) and bacteria (AOB). The AOA/AOB ratio of each treatment is shown on the top of the column. N0, non-N-fertilized control; N52.5, N105, N157.5, N210, annual N fertilizer application at 52.5, 105.0, 157.0, and $210.0 \mathrm{~kg} \mathrm{~N}^{-1}$, respectively. Error bars indicate the standard errors of the means $(n=3)$. Significant differences are based on $\mathrm{AOA}$ and AOB Permanova analyses separately, and the different letters indicate means that are significantly different at $p<0.05$.

AOA abundance showed significantly positive correlations with soil $\mathrm{pH}$ and NUE, and negative correlation with soil $\mathrm{NH}_{4}-\mathrm{N}, \mathrm{NO}_{3}-\mathrm{N}, \mathrm{PNA}$, and grain yield (Table 2). AOB abundance was positively correlated with soil $\mathrm{TN}, \mathrm{NO}_{3}-\mathrm{N}, \mathrm{TP}, \mathrm{AP}, \mathrm{PNA}$, and grain yield, but negatively correlated with soil $\mathrm{pH}$ and NUE. The ratio of $\mathrm{AOA} / \mathrm{AOB}$ positively correlated with soil $\mathrm{pH}$ and $\mathrm{NUE}$, and negatively correlated with soil $\mathrm{NH}_{4}-\mathrm{N}, \mathrm{NO}_{3}-\mathrm{N}, \mathrm{AP}, \mathrm{PNA}$, and grain yield. In addition, soil PNA had significant positive correlations with soil TN concentration, $\mathrm{NO}_{3}-\mathrm{N}$ concentration, and grain yield.

Table 2. Pearson's correlations analysis between soil properties, grain yield (GY), nitrogen use efficiency (NUE), potential nitrification activity (PNA), and abundances of AOA and AOB.

\begin{tabular}{ccccccccccc}
\hline & $\mathbf{p H}$ & $\mathbf{T N}$ & $\mathbf{N H}_{4}-\mathbf{N}$ & $\mathbf{N O}_{3}-\mathbf{N}$ & $\mathbf{T P}$ & $\mathbf{A P}$ & $\mathbf{S M}$ & GY & NUE & PNA \\
\hline AOA & $0.900^{* *}$ & -0.348 & $-0.728^{* *}$ & $-0.863^{* *}$ & -0.490 & -0.470 & 0.320 & $-0.893^{* *}$ & $0.895^{* *}$ & $-0.580^{*}$ \\
$\mathrm{AOB}$ & $-0.802^{* *}$ & $0.563^{*}$ & $0.443^{*}$ & $0.605^{*}$ & $0.515^{*}$ & $0.661^{* *}$ & -0.225 & $0.860^{* *}$ & $-0.661^{* *}$ & $0.787^{* *}$ \\
$\mathrm{AOA} / \mathrm{AOB}$ & $0.888^{* *}$ & -0.412 & $-0.596^{*}$ & $-0.763^{* *}$ & -0.513 & $-0.573^{*}$ & 0.273 & $-0.868^{* *}$ & $0.872^{* *}$ & $-0.685^{* *}$ \\
PNA & -0.480 & $0.660^{* *}$ & 0.328 & $0.674^{* *}$ & 0.320 & 0.135 & -0.015 & $0.758^{* *}$ & -0.479 & - \\
\hline
\end{tabular}

The values are correlation coefficients $*<0.05 ;{ }^{* *} p<0.01$. 


\subsection{Richness and Diversity of $A O A$ and $A O B$}

All AOA sequences with a sequence similarity of $97 \%$ were clustered into 48 OTUs, of which 7 OTUs had relative abundance $>0.1 \%$ (Figure 2). Based on the phylogenetic tree, only 3 AOA OTUs (OTU 1, OTU 2, and OTU 6) could be grouped into one Candidatus Nitrosocosmicus (Figure 2a). OTU 1 predominated across all five treatments (up to 97\%). Among these 7 OTUs, only the relative abundance of OTU 1 (97.97\%) under the N105 treatment increased significantly (Figure $2 b$ ).

(a)

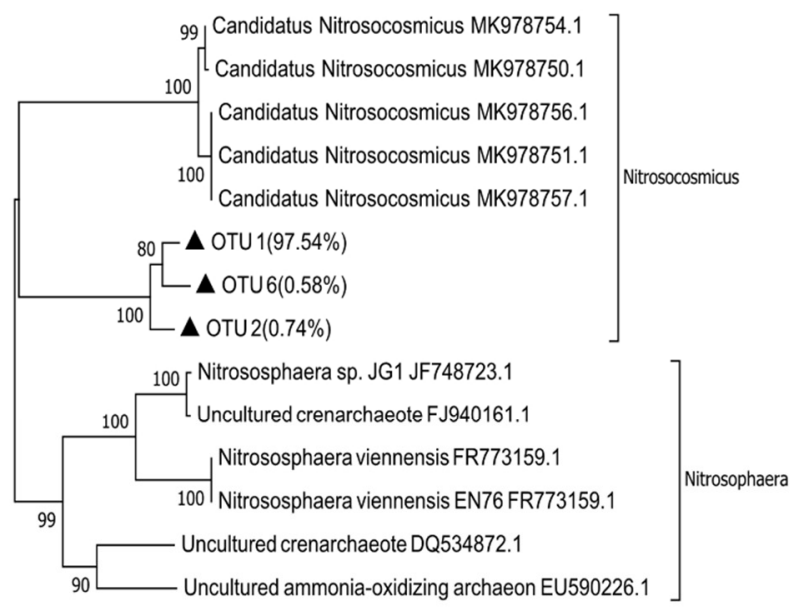

(b)

$\stackrel{\longmapsto}{0.02}$

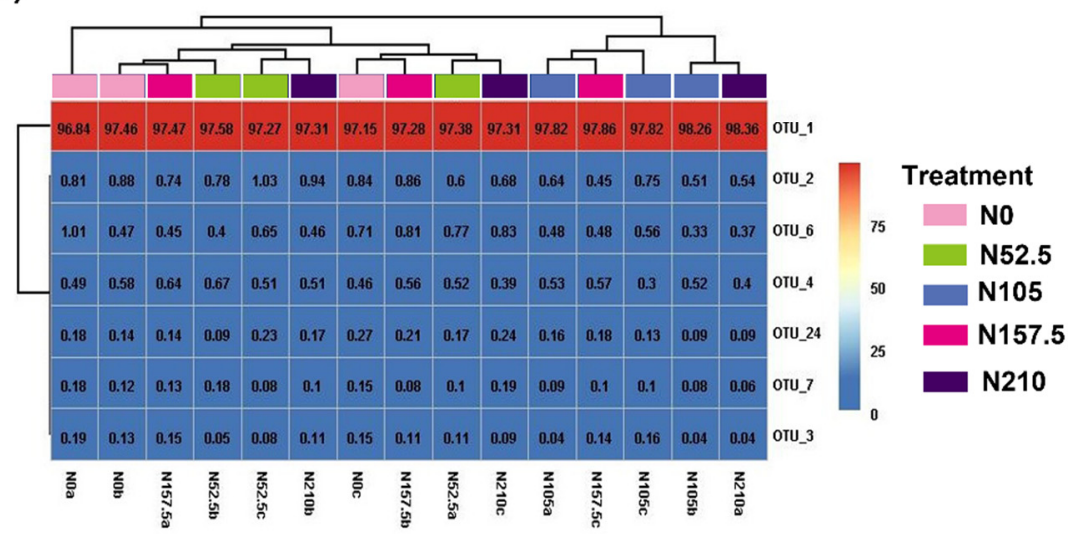

Figure 2. Neighbor-joining phylogenetic tree (a) and heatmap (b) for representative AOA OTUs (representatives with top 7 relative abundances) under N0, N52.5, N105, N157.5, and N210 treatments. OTUs from this study are depicted by closed triangle. Numbers in brackets represent the total relative abundances of OTUs for each branch. Bootstrap values ( $>50 \%)$ are indicated at branch points. The scale bar represents $2 \%$ sequence divergence. The color from blue to red indicates the relative abundance of AOA OTUs from least to most. The number in each text indicates the relative abundance value of each OTU in the sample. a, b, and c represent the first, second, and third experimental replications, respectively, for the corresponding treatment.

All AOB with a sequence similarity of $97 \%$ were clustered into 693 OTUs, of which 23 OTUs had relative abundance $>0.2 \%$ (Figure 3 ). Phylogenetically, only 10 AOB OTUs could be grouped into one Nitrosospira cluster 3 (Figure 3a). OTU 1, OTU 6, OTU 8, and OTU 11 were identified as unclassified Nitrosospira genus. OTU 2, OTU 4, OTU 9, and OTU 45 were identified as Nitrosospira briensis species, while OTU 19 and OTU 22 were identified as Nitrosospira species Nsp40. OTU 4 was the most abundant, accounting for $37.9 \%$ of the total readings, followed by OTU $9(13.85 \%)$ (Figure $3 b)$. Additionally, among the five treatments, the relative abundance of OTU $12(p=0.025)$, OTU $7(p=0.040)$, OTU $46(p=0.009)$, OTU 
$45(p=0.023)$, and OTU $64(p=0.013)$ significantly differed with the $\mathrm{N}$ treatments. The relative abundance of OTU 12 was significantly higher under N105 treatment $(9.33 \%)$ than under the other treatments; the relative abundance of OTU 7 in N210 (1.85\%) and N157.5 treatments $(2.20 \%)$ were significantly lower than that of N0 treatment $(5.60 \%)$.

$\mathrm{N}$ fertilizer rates had significant impacts on the AOB diversity as shown by Chao1, Simpson, and Shannon indexes, rather than AOA diversity $(p>0.05)$ (Figure 4$)$. Among five treatments, the N210 treatment had greater Chao1 for AOA than the N0 treatment (Figure 4a), while the N105 treatment had lower Simpson and Shannon indexes for AOA than the N0 treatment (Figure 4b,c). The N105 and N210 treatments had the greatest and lowest Chao1, Simpson, and Shannon indexes for AOB, respectively (Figure $4 \mathrm{~d}-\mathrm{f}$ ).

\section{4. $A O A$ and $A O B$ Community}

As for the AOA community, approximately 100\% of AOA reads were assigned to the phylum Thaumarchaeota. Candidatus Nitrosocosmicus and Nitrososphaera were the two dominating AOA genera representing 99.97-99.99\% and $0.01-0.02 \%$ of the total sequences (Figure S1a). Among the five treatments, the composition of the AOA community did not differ significantly. As for the AOB community, 100\% of reads were assigned to the phylum Proteobacteria. Nitrosospira and Nitrosomonas were the dominant genera of AOB, representing $99.96-100 \%$ and $0.00-0.04 \%$ of the total sequences, respectively, while $30.81 \%-42.90 \%$ genus of Nitrosospira and 0.00-0.04\% genus of Nitrosomonas were unclassified (Figure S1b). N fertilizer rates had significant impacts on the AOB community. Among the five treatments, N210 and N157.5 showed a higher relative abundance of Nitrosospira but a low relative abundance of unclassified Nitrosospira compared to those under the N52.5 and no-N control.

The principal coordinate analysis (PCOA) results showed differences in the community structure of AOA and AOB under different $\mathrm{N}$ fertilizer treatments (Figure S2). Total variance for AOA was 34.9\% and 13.3\% (Figure S2a), while variance for AOB was 17.9\% and $13.8 \%$ (Figure S2b), explained by PCoA1 and PCoA2, respectively. There was one major cluster in the community structure of AOB at N105 treatment, while the samples of N0 and N210 treatments had different community composition patterns and were separated from the major cluster (Figure S2b). However, no major clusters were found in the community structure of AOA (Figure S2a).

\subsection{Network Associations among OTUs of AOB Species}

A correlation-based network was constructed with the OTUs of AOB species to reveal potential co-occurrence between the microbial groups in different $\mathrm{N}$ fertilizer treatments (Figure 5). The network showed 52 neighbors, and the average path length was 3.20. The modularity value was only 0.9 , suggesting that the AOB network was modular. Among the AOB network, 23 nodes (17\% of the total nodes) were assigned to Nitrosospira briensis species, 61 nodes (45\%) assigned to Nitrosospira unclassified species, one node ( $2 \%$ ) assigned to Nitrosospira Np39-19 species (OTU 32), and the other nodes (37\%) assigned to null species. However, the OTUs of AOA species failed to form a co-occurrence network based on correlation.

\subsection{Correlation of Ammonia-Oxidizing Communities with the Soil Properties}

The correlation among alpha indices of AOA and AOB diversity, soil properties, and PNA is shown in Table 3. In the AOA community, $\mathrm{pH}$ was correlated with Simpson index and negatively correlated with Chao1 and Simpson index; $\mathrm{NO}_{3}-\mathrm{N}$ was positively correlated with chao1 and Observed species index, while $\mathrm{NH}_{4}-\mathrm{N}$ was only positively correlated with Observed species index; both AP and PNA was negatively correlated with Simpson, Shannon, and Pielou_e index. In AOB community, $\mathrm{pH}$ was only positively correlated with Pielou_e index; $\mathrm{NH}_{4}-\mathrm{N}$ was negatively correlated with Simpson, Shannon, and Pielou_e index, while $\mathrm{NO}_{3}-\mathrm{N}$ was only negatively correlated with Simpson index; AP was positively correlated with Chao1 and Observed species index; PNA was positively correlated with Chao1 and Shannon index. 
(a)

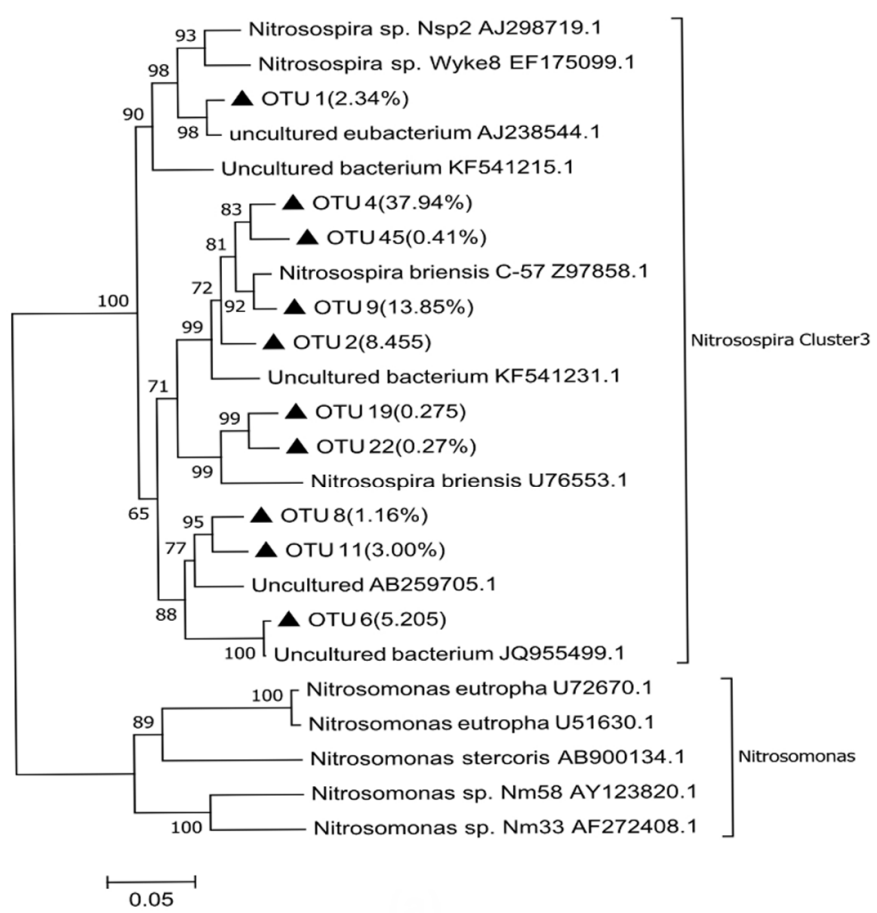

(b)

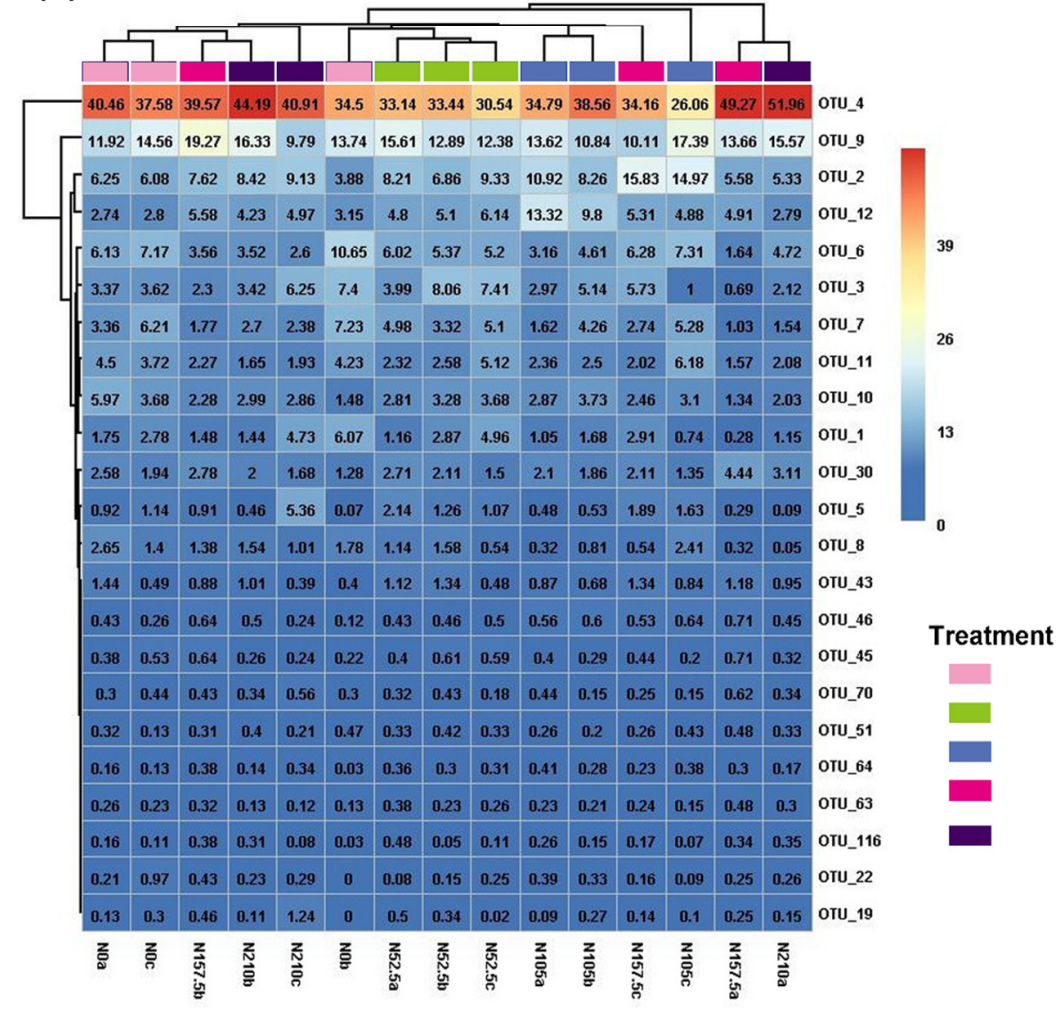

Figure 3. Neighbor-joining phylogenetic tree (a) and heatmap (b) for representative AOB OTUs (representatives with top 23 relative abundances) under N0, N52.5, N105, N157.5, and N210 treatments. OTUs from this study are depicted by closed triangle. Numbers in brackets represent the total relative abundances of OTUs for each branch. Bootstrap values $(>50 \%)$ are indicated at branch points. The scale bar represents $5 \%$ sequence divergence. The color from blue to red indicates the relative abundance of AOA OTUs from least to most. The number in each text indicates the relative abundance value of each OTU in the sample. a, b, and c represent the first, second, and third experimental replications, respectively, for the corresponding treatment. 

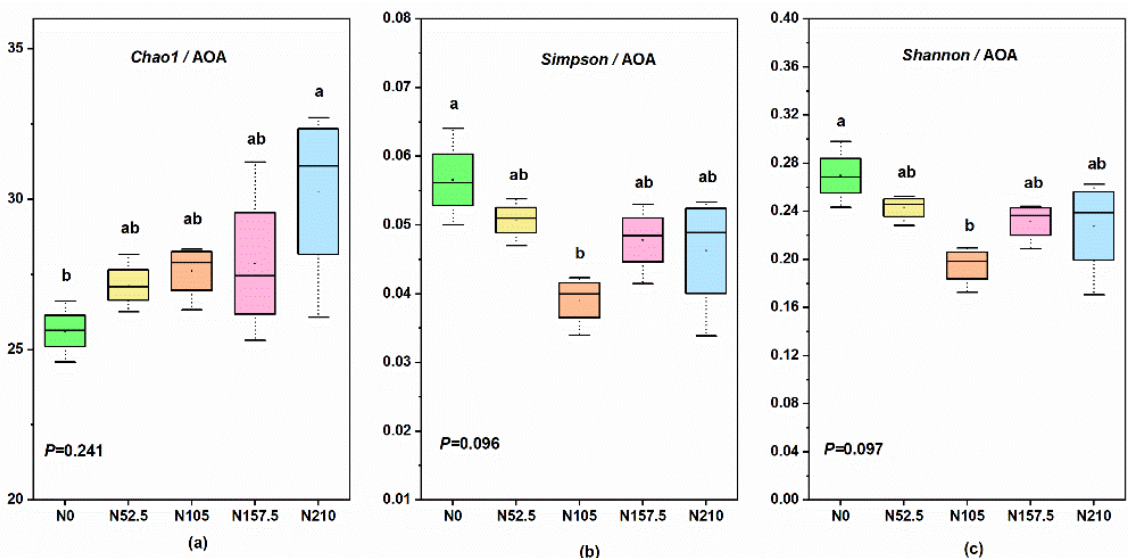

(c)
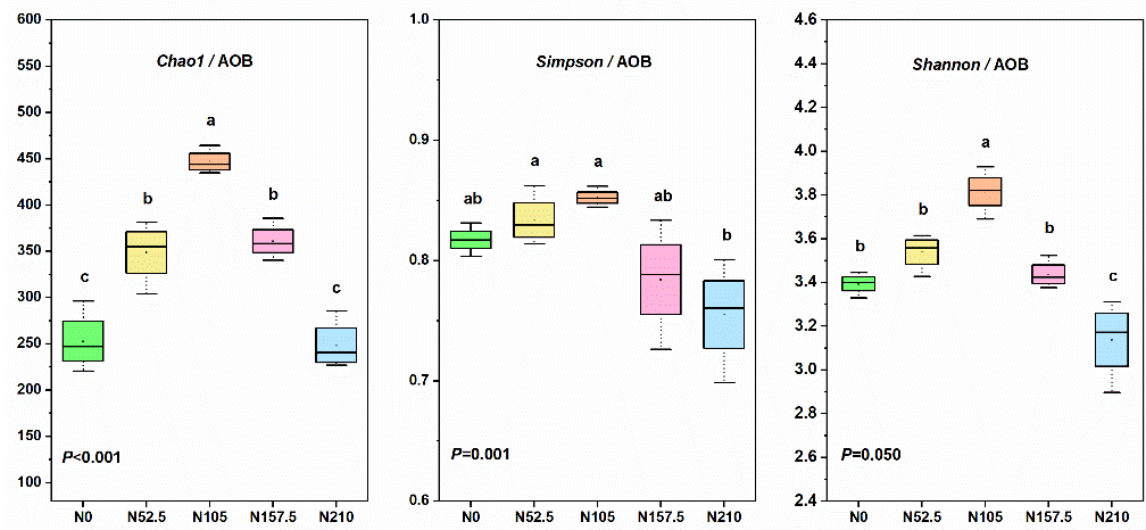

(e)

Figure 4. Alpha diversity of AOA and AOB according to the Chao1 (a,d), Simpson (b,e), and Shannon $(\mathbf{c}, \mathbf{f})$ indexes as affected by long-term nitrogen $(\mathrm{N})$ fertilizer treatment. N0, non-N-fertilized control; N52.5, N105, N157.5, N210, annual N fertilizer application at 52.5, 105.0, 157.5, and $210.0 \mathrm{~kg} \mathrm{~N} \mathrm{ha}^{-1}$, respectively. Boxplots with different letters indicate means that are significantly different at $p<0.05$.

Table 3. Pearson's correlation among alpha diversity index of AOA and AOB, soil properties, and potential nitrification activity (PNA).

\begin{tabular}{cccccccccc}
\hline Item & Alpha Index & $\mathbf{p H}$ & $\mathbf{T N}$ & $\mathbf{N H}_{\mathbf{4}}-\mathbf{N}$ & $\mathbf{N O}_{3}-\mathbf{N}$ & $\mathbf{T P}$ & $\mathbf{A P}$ & $\mathbf{S M}$ & PNA \\
\hline \multirow{6}{*}{ AOA } & Chao1 & $-0.554^{*}$ & 0.128 & 0.450 & $0.589^{*}$ & -0.112 & 0.284 & -0.463 & 0.080 \\
& Simpson & $0.524^{*}$ & -0.323 & -0.254 & -0.330 & -0.328 & $-0.665^{* *}$ & 0.088 & $-0.700^{* *}$ \\
& Shannon & 0.510 & -0.297 & -0.236 & -0.309 & -0.387 & $-0.688^{* *}$ & 0.031 & $-0.713^{* *}$ \\
& Pielou_e & 0.474 & -0.222 & -0.262 & -0.335 & -0.219 & $-0.639^{*}$ & 0.122 & $-0.623^{*}$ \\
& Observed species & $-0.545^{*}$ & 0.157 & $0.715^{* *}$ & $0.696^{* *}$ & 0.165 & 0.162 & -0.386 & 0.023 \\
\hline \multirow{4}{*}{ AOB } & Chao1 & -0.304 & 0.327 & -0.189 & -0.095 & 0.396 & $0.715^{* *}$ & 0.166 & $0.703^{* *}$ \\
& Simpson & 0.412 & 0.087 & $-0.711^{* *}$ & $-0.616^{*}$ & 0.188 & 0.058 & 0.144 & 0.357 \\
& Shannon & 0.062 & 0.422 & $-0.529^{*}$ & -0.448 & 0.157 & 0.282 & 0.111 & $0.535^{*}$ \\
& Pielou_e & $0.530^{*}$ & -0.186 & $-0.578^{*}$ & -0.497 & 0.299 & -0.182 & 0.206 & 0.241 \\
& Observed species & -0.420 & $0.618^{*}$ & -0.149 & -0.095 & 0.036 & $0.547^{*}$ & 0.067 & 0.488 \\
\hline
\end{tabular}

Correlation coefficients followed by * and ${ }^{* *}$ are significant at $p<0.05$ and $p<0.01$, respectively.

For the AOA community, RDA results showed that the first axis explained $28 \%$ variation and the second axis explained $8.2 \%$ variation (Figure $6 \mathrm{a}$ ). Moisture showed a significant influence on the AOA community $(72.6 \%, p=0.020)$. For the AOB community structure, the first axis explained $31 \%$ variation and the second axis explained $7 \%$ variation (Figure $6 \mathrm{~b}$ ). The $\mathrm{NH}_{4}-\mathrm{N}$ was the most determinant of structuring the $\mathrm{AOB}$ community $(67.3 \%, p=0.004)$. Thus, $\mathrm{AOA}$ and $\mathrm{AOB}$ communities were closely related to soil properties. 


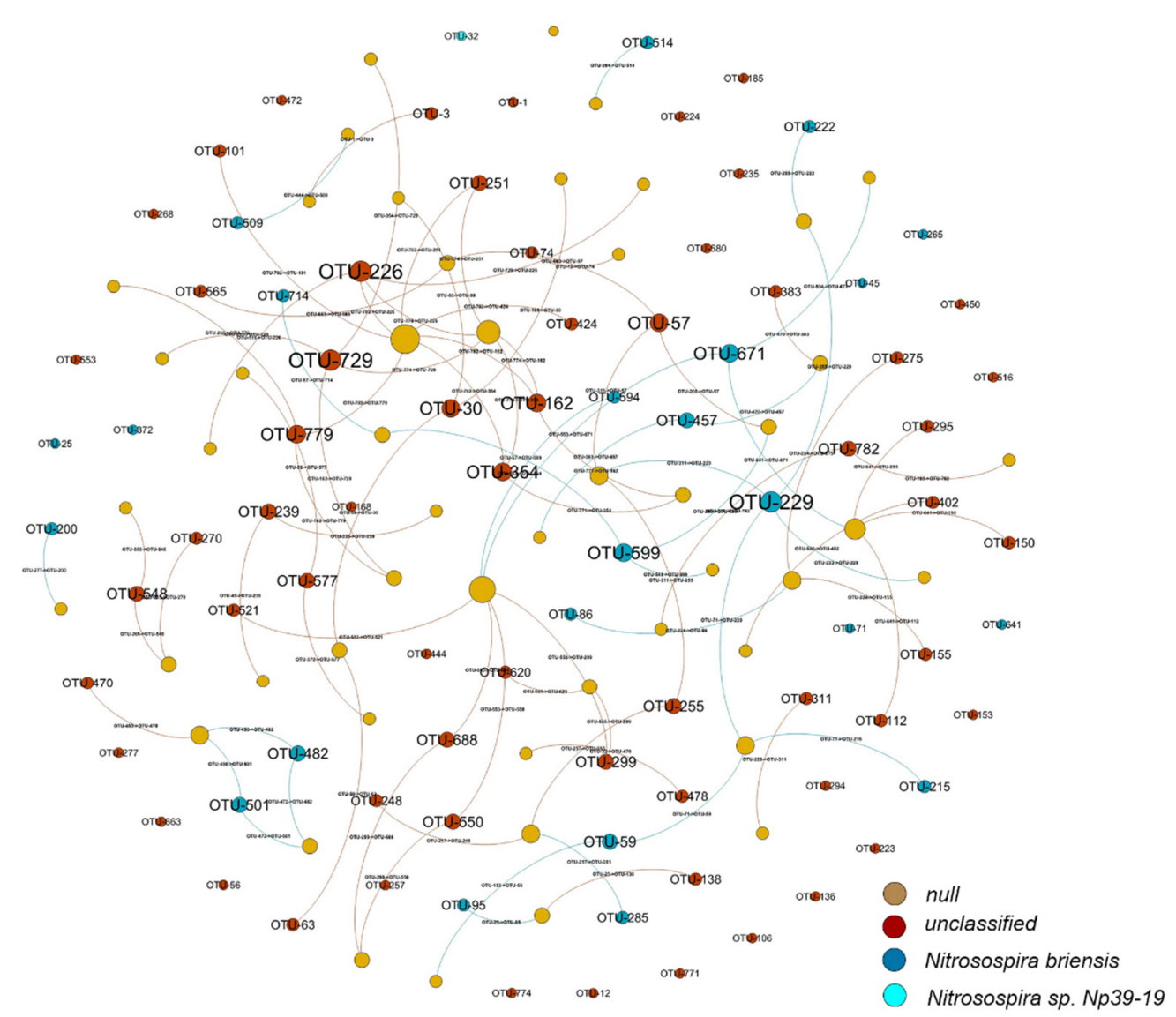

Figure 5. Co-occurrence network based on AOB OTUs across the different $\mathrm{N}$ fertilizer treatments. Nodes represent different OTUs, and these OTUs are colored by modules. The size of each node is proportional to the number of connections (its degree). The widths of each connection between two nodes (edges) are scaled according to its weight, and the edge color is derived from the nodes to which they are connected. The label shows the phylogenetic relationship of each node down to the AOB species level.

The correlation between AOA (Figure 7a) and AOB abundance (Figure $7 \mathrm{~b}$ ) at the genera level and soil properties was further determined using a correlation heatmap. Soil $\mathrm{NO}_{3}-\mathrm{N}$ was positively correlated with AOA genus Nitrososphaera $(r=0.526, p=0.044)$ and AOB genus Nitrosospira_sp_Nitrosospira_briensis $(r=0.775, p=0.001)$, and negatively correlated with AOA genus Candidatus Nitrosocosmicus $(r=-0.526, p=0.044)$ and AOB genus Nitrosospira_sp_unclassified ( $r=-0.777, p=0.001)$. Soil moisture was positively correlated with AOA genus Candidatus Nitrosocosmicus $(r=0.587, p=0.021)$, and negatively correlated with AOA genus Nitrososphaera $(r=-0.587, p=0.021)$ and AOB genus Nitrosomonas_sp_unclassified ( $r=-0.780, p=0.001$ ). Soil $\mathrm{NH}_{4}-\mathrm{N}$ concentration was positively correlated with AOB genus Nitrosospira_sp_Nitrosospira_briensis $(r=0.773, p=0.001)$, and negatively correlated with AOB genus Nitrosospira_sp_unclassified $(r=-0.780, p=0.001)$. Soil $\mathrm{pH}$ was positively correlated with AOB genus Nitrosospira_sp_Nv6x $(r=621, p=0.013)$ and Nitrosospira_sp_unclassified ( $r=728, p=0.002)$, and negatively correlated with AOB genus $\mathrm{Ni}$ trosospira_sp_Nitrosospira_briensis $(r=-0.731, p=0.002)$. The soil available phosphorus concentration was only negatively correlated with AOB genus Nitrosospira_sp_L115 $(r=-0.599$, $p=0.018)$, Nitrosospira_sp_Np39_19 $(r=-0.607, p=0.016)$, and Nitrosospira_sp_Nl20 $(r=-0.681, p=0.005)$. Total nitrogen concentration was negatively correlated with AOB genus Nitrosospira_sp_PJA1 $(r=-0.523, p=0.046)$. In addition, GY was positively correlated with AOB genus Nitrosospira_sp_Nitrosospira_briensis $(r=0.725, p=0.002)$, and negatively correlated with AOB genus Nitrosospira_sp_unclassified $(r=-0.709, p=0.003)$. NUE was positively correlated with AOB genus Nitrosospira_sp_Nv6x $(r=0.732, p=0.002)$ and $\mathrm{Ni}$ - 
trosospira_sp_unclassified $(r=0.583, p=0.023)$, but negatively correlated with AOB genus Nitrosospira_sp_Nitrosospira_briensis $(r=-0.580, p=0.024)$.

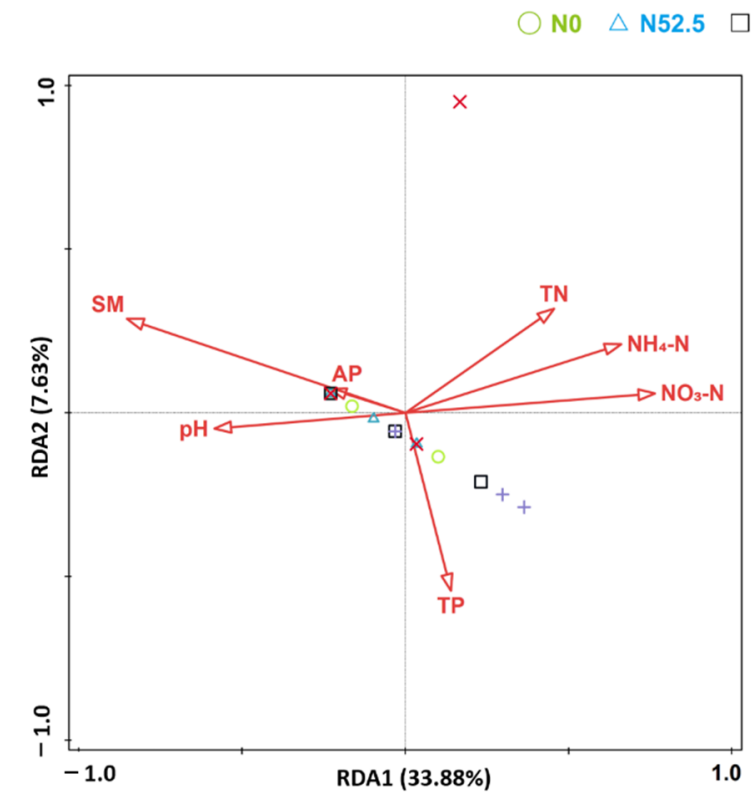

(a)

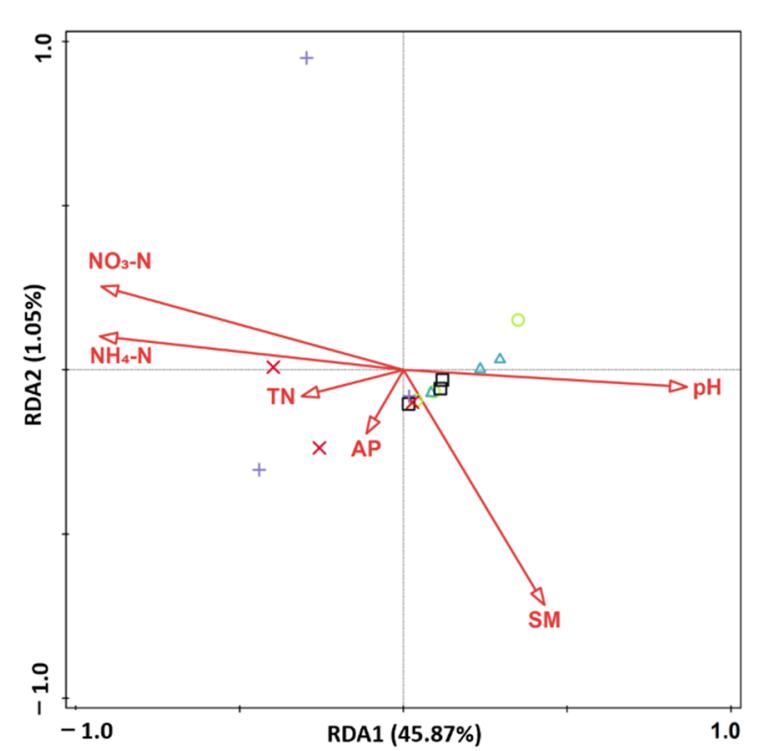

(b)

Figure 6. Redundancy analysis (RDA) of (a) AOA and (b) AOB communities based on soil parameters and PNA. N0, non-N-fertilized control; N52.5, N105, N157.5, N210, annual N fertilizer application at $52.5,105.0,157.5$, and $210.0 \mathrm{~kg} \mathrm{~N}^{-1}$, respectively. $\mathrm{pH}$, soil $\mathrm{pH}, \mathrm{TN}$, soil total nitrogen; $\mathrm{NH}_{4}-\mathrm{N}$, soil ammonium-N; $\mathrm{NO}_{3}-\mathrm{N}$, soil nitrate-N; $\mathrm{TP}$, soil total phosphorus; $\mathrm{AP}$, soil available phosphorus; $\mathrm{SM}$, soil moisture.

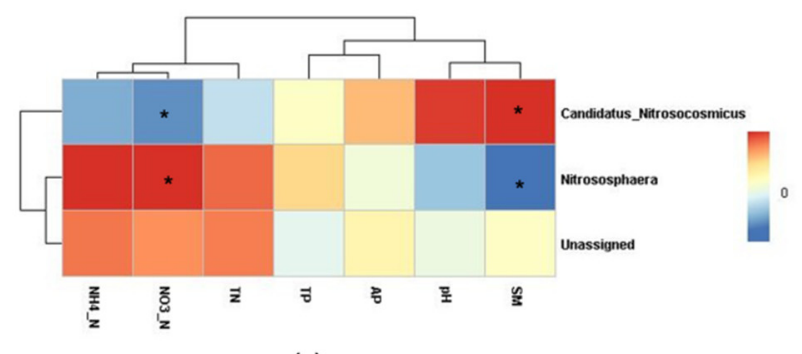

(a)

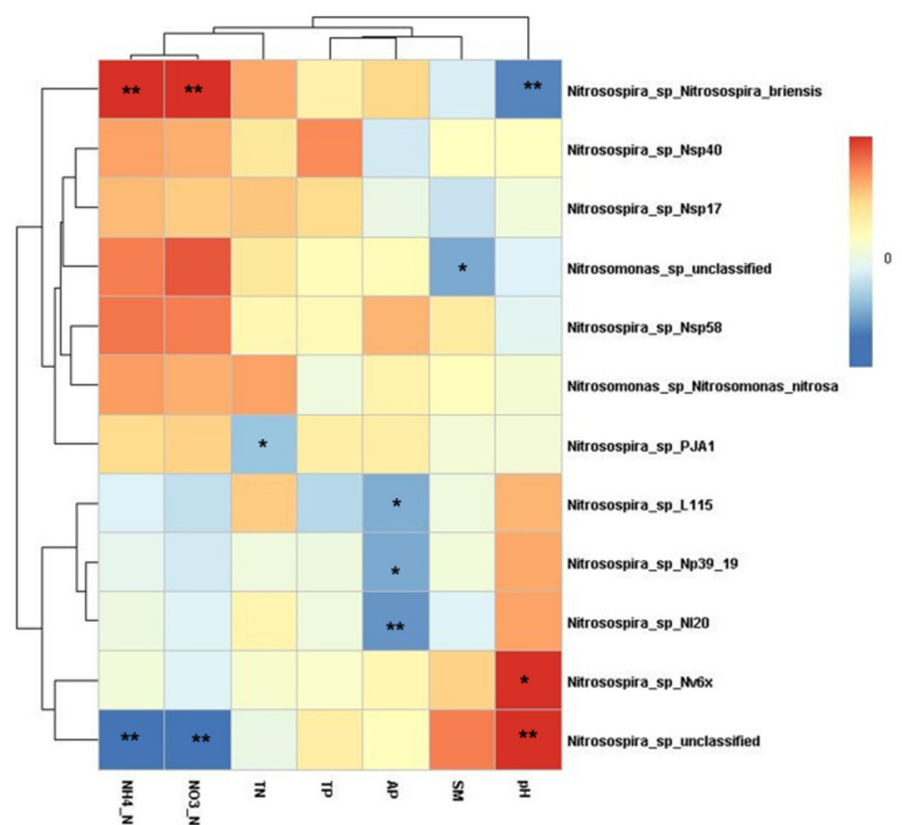

(b)

Figure 7. Correlation heatmap of relative abundances of $\mathrm{AOA}(\mathbf{a})$ and $\mathrm{AOB}(\mathbf{b})$ and soil properties at the genus level. $\mathrm{pH}$, soil $\mathrm{pH}, \mathrm{TN}$, soil total nitrogen; $\mathrm{NH}_{4}-\mathrm{N}$, soil ammonium- $\mathrm{N}$; $\mathrm{NO}_{3}-\mathrm{N}$, soil nitrate-N; TP, soil total phosphorus; AP, soil available phosphorus; SM, soil moisture. The shade of color indicates the correlation between relative abundance of each genus and soil parameters. ${ }^{*} p<0.05 ;{ }^{* *} p<0.01$. 


\section{Discussion}

\subsection{Effect of $N$ Fertilization on $A O A$ and $A O B$ Abundances}

Nitrogen $(\mathrm{N})$ addition is crucial for agriculture production and influences the microbial communities [58]. The coexistence of AOA and AOB has been studied in various types of soil $[59,60]$. This study showed that AOA and AOB communities responded differentially to $\mathrm{N}$ fertilizer application rates (Figure 1 ). The gene copies vary from $1.05 \times 10^{7}$ to $4.88 \times 10^{7}$ copies $^{-1}$ of dry soil for amo A AOA and $3.63 \times 10^{7}$ to $8.24 \times 10^{7}$ copies g $^{-1}$ of dry soil for amoA AOB. The ratio of AOA to AOB (0.16 to 1.34 ) was lower than previous studies (17 to 1600) [6,40], which was inconsistent with the previous conclusion that the AOA community dominates agricultural soils [37-39]. Compared with the no-N control, the $\mathrm{N}$ fertilizer application rate significantly increased AOB abundance (by 50-127\%) and decreased AOA abundance (by 48-78\%), suggesting that AOB preferred nutrient-rich environments, while AOA was likely more suitable for nutrient-deficient environments [61-63]. This study found that $\mathrm{N}$ fertilizer rates significantly increased AOB abundance but had little effect on the AOA abundance.

Inorganic $\mathrm{N}$ is used as an energy source for the colonization and growth of the AOB community $[18,64]$. The significantly positive correlation between AOB abundance and $\mathrm{TN}$ further showed that $\mathrm{N}$ had an important role in the growth of AOB. Higher ammonia $\left(\mathrm{NH}_{4}{ }^{-}\right)$substrates are beneficial to the growth of $\mathrm{AOB}$, while low ammonia $\left(\mathrm{NH}_{4}{ }^{-}\right)$substrates are beneficial to the growth of AOA [65]. Compared with AOB, AOA was more favorable for lower concentrations of soil $\mathrm{NH}_{4}{ }^{+}$and $\mathrm{NO}_{3}{ }^{-}$, as well as higher $\mathrm{pH}$, which contributed to increased wheat NUE (Table 2). In contrast, increasing $\mathrm{NO}_{3}{ }^{-}$concentrations and decreasing soil $\mathrm{pH}$ facilitate $\mathrm{AOB}$ growth, thereby increasing the yield of wheat grains. Our results contradict the studies of Nicol et al. [66] on grazed grassland soils ( $\mathrm{pH}$ in the range of 4.9-7.5), which might be because of different soil types. In summary, soil $\mathrm{pH}$, $\mathrm{NO}_{3}-\mathrm{N}$, and $\mathrm{NH}_{4}-\mathrm{N}$ were the main reasons for the difference in the abundance of AOA and AOB. In addition, soil total phosphorus, total $\mathrm{N}$, and available phosphorus also affected the AOB abundance, while soil moisture did not affect AOA and AOB (Table 2), inconsistent with the study of Yang et al. [67] on irrigated soil.

\subsection{Composition of $A O A$ and $A O B$}

Previous studies showed a significant impact of $\mathrm{N}$ fertilizers on the AOA communities in acidic soil $[15,68]$ and the AOB communities in alkaline sandy soil [37]. The increase in abundance and activity of AOB usually exceeds that of AOA after adding N fertilizer [69,70]. The present study showed that AOA and AOB communities responded differently to $\mathrm{N}$ fertilizer application rates. Application of different $\mathrm{N}$ rates had significant impacts on the diversity of AOB but no significant effect on the diversity of AOA (Figure 4). In addition, soil samples applied with $105 \mathrm{~kg} \mathrm{~N} \mathrm{ha}^{-1}$ had lower diversity of AOA while having greater diversity of AOB (Figure 4), indicating that the optimum $\mathrm{N}$ fertilizer rate would increase the diversity of AOB [58].

The Thaumarchaeota group is widely distributed and the dominant archaea in terrestrial systems [71,72]. We found that approximately $100 \%$ of AOA reads belonged to the Thaumarchaeota, and $100 \%$ of AOB reads belonged to the Proteobacteria at the phylum level. At the genera level, Candidatus Nitrosocosmicus (>99.9\%) was the most dominant AOA genus, and Nitrosospira (>99.9\%) was the most dominant AOB genus (Figure S1), which was consistent with many previous studies [73-75]. Song et al. [76] reported that Nitrosomonas generally prefers neutral soils and Nitrosospira prefers acidic soils. However, the tested soil was alkaline soils ( $\mathrm{pH} 8.67-8.99)$, Nitrosomonas was also found in AOB but had a low abundance $(<0.01 \%)$ (Figure S1). Nitrosospira is often the most abundant in semi-arid soil $[58,77,78]$. The study found that at the higher N-treatments (N210 and N157.5), soil had a greater abundance of Nitrosospira and lower abundance of unclassified Nitrosospira than the lower N-treatment (N52.5) or no-N (N0), suggesting that it is necessary to re-determine the conclusion that Nitrosospira prefers low-N environments [79], considering its sub-classification. This study also found a major cluster in the AOB community structure, suggesting that 
the AOB community is more stable in the soil at the optimum $\mathrm{N}$ rate $\left(105 \mathrm{~kg} \mathrm{~N} \mathrm{ha}^{-1} \mathrm{yr}^{-1}\right)$ (Figure S2). However, AOA communities were relatively insensitive to different rates of $\mathrm{N}$ fertilizer, consistent with the study of Tao et al. [39].

Microbial communities interact under different $\mathrm{N}$ fertilizer treatments [80]. This result showed that $17 \%$ and $45 \%$ of total nodes among the keystone species of the AOB network were assigned to Nitrosospira briensis and Nitrosospira unclassified species, respectively (Figure 5), while AOA species failed to form a co-occurrence network based on correlation. PNA was correlated with the AOB community (with a contribution of $16.6 \%$ ), but not correlated with the AOA community (Figure 6), indicating that the nitrification in the alkaline soil tested in this study was mainly driven by AOB community. In our study, AOB was the main ammonia-oxidizing community, which was also corroborated in other studies in semi-arid soils $[18,46,59]$.

\subsection{Relationships between Soil Properties and $A O A$ and $A O B$ Communities}

The application of $\mathrm{N}$ fertilizers affects many plant-soil characteristics, such as crop yield, nitrogen use efficiency (NUE), and soil properties, which are all important factors that determine the soil microbial habitat [17,81]. Distance-based redundancy analysis (RDA) showed that soil moisture was the most important factor affecting AOA community (72.6\% contribution) (Figure 6). Similarly, Yang et al. [67] reported that soil moisture was the dominant factor controlling AOA communities. Moreover, AOA genus Candidatus Nitrosocosmicus abundance was also significantly negatively correlated with $\mathrm{NO}_{3}-\mathrm{N}$ concentration (Figure 7), which is also because AOA is more suitable for nutrient-deficient environments [63]. Similarly, soil $\mathrm{NH}_{4}-\mathrm{N}$ was the dominant factor controlling AOB communities (with a contribution of $72 \%$ ), which showed that $\mathrm{N}$ fertilization-induced $\mathrm{NH}_{4}-\mathrm{N}$ concentration changes were the dominant factor controlling the AOB communities. In addition, AOB genus Nitrosospira abundance was also positively correlated with $\mathrm{NO}_{3}-\mathrm{N}$ and negatively correlated with soil $\mathrm{pH}$, which is also because AOB prefers nutrient-rich and lower $\mathrm{pH}$ environments $[15,63,68]$.

\section{Conclusions}

Long-term different rates of $\mathrm{N}$ fertilizer led to the increase of soil $\mathrm{NH}_{4}-\mathrm{N}, \mathrm{NO}_{3}-\mathrm{N}$ concentrations, and AOB abundance, and the decrease of soil pH and AOA abundance. Among soil physicochemical parameters, moisture was the most important contributor to the AOA community, whilst $\mathrm{NH}_{4}-\mathrm{N}$ was the most important contributor to the AOB community. The application of $\mathrm{N}$ fertilizer had a more significant impact on the diversity and community of AOB than AOA in this weak alkaline soil. The predominant phyla of AOA and AOB phyla were Thaumarchaeota and Proteobacteria, respectively. Excessive N fertilization resulted in a significant decrease in the relative abundance of genus Nitrosospira. $\mathrm{N}$ fertilization rate of $105 \mathrm{~kg} \mathrm{~N} \mathrm{ha}^{-1} \mathrm{yr}^{-1}$ obtained the greatest AOB diversity, the gene copy of amo A AOB $\left(8.24 \times 10^{7}\right.$ copies $\mathrm{g}^{-1}$ dry soil), and wheat yield $(49 \%$ higher than control) for sustainable wheat production in a semi-arid area.

Supplementary Materials: The following supporting information can be downloaded at: https: / / www.mdpi.com/article/10.3390/ijerph19052732/s1, Figure S1: Relative abundance of AOA genera (a) and AOB genera (b) in the soils as affected by long-term nitrogen $(\mathrm{N})$ fertilizer treatment; Figure S2: Principal coordinate analysis (PCoA) of AOA (a) and AOB (b) as affected by long-term nitrogen (N) fertilizer treatment.

Author Contributions: Conceptualization, L.L.; data curation, J.X., Z.L. and L.C.; formal analysis, R.Z.; funding acquisition, L.L.; investigation, A.X. and L.W.; methodology, A.X., Z.L., and L.C.; project administration, J.X.; resources, Z.L., L.C. and C.L.; software, A.X. and Y.J.; validation, L.L.; visualization, Y.J.; writing-original draft, A.X.; writing—review and editing, L.L., S.A. and S.G. All authors have read and agreed to the published version of the manuscript. 
Funding: This study was funded by the Education Science and Technology Innovation Project of Gansu Province(GSSYLXM-02), the National Natural Science Foundation of China (31761143004 and 41922048).

Acknowledgments: The authors appreciate assistance in the field and laboratory by students of the Rainfed Agricultural Experimental Station of Gansu Agricultural University.

Conflicts of Interest: The authors declare no conflict of interest.

\section{References}

1. Hatzenpichler, R. Diversity, physiology, and niche differentiation of ammonia-oxidizing archaea. Appl. Environ. Microbiol. 2012, 78, 7501-7510. [CrossRef] [PubMed]

2. Yin, Z.; Bi, X.; Xu, C. Ammonia-Oxidizing Archaea (AOA) Play with Ammonia-Oxidizing Bacteria (AOB) in Nitrogen Removal from Wastewater. Archaea 2018, 2018, 8429145. [CrossRef] [PubMed]

3. Mukhtar, H.; Lin, Y.-P.; Anthony, J. Ammonia Oxidizing Archaea and Bacteria in East Asian Paddy Soils-A Mini Review. Environments 2017, 4, 84-92. [CrossRef]

4. Kool, D.M.; Dolfing, J.; Wrage, N.; Van Groenigen, J.W. Nitrifier denitrification as a distinct and significant source of nitrous oxide from soil. Soil Biol. Biochem. 2011, 43, 174-178. [CrossRef]

5. Zhu, X.; Burger, M.; Doane, T.A.; Horwath, W.R. Ammonia oxidation pathways and nitrifier denitrification are significant sources of N2 and NO under low oxygen availability. Proc. Natl. Acad. Sci. USA 2013, 110, 6328-6333. [CrossRef] [PubMed]

6. Adair, K.L.; Schwarta, F. Evidence that ammonia-oxidizing archaea are more abundant than ammonia-oxidizing bacteria in semiarid soils of northern Arizona, USA. Microb. Ecol. 2008, 56, 420-426. [CrossRef] [PubMed]

7. Kowalchuk, G.A.; Stephen, J.R. Ammonia-oxidizing bacteria: A model for molecular microbial ecology. Annu. Rev. Microbiol. 2001, 55, 485-529. [CrossRef] [PubMed]

8. Prosser, J.I. Soil Nitrifiers and Nitrification; ASM Press: Washington, DC, USA, 2011; pp. 347-381.

9. Li, Y.; Ding, K.; Wen, X.; Zhang, B.; Shen, B.; Yang, Y. A novel ammonia-oxidizing archaeon from wastewater treatment plant: Its enrichment, physiological and genomic characteristics. Sci. Rep. 2016, 6, 23747. [CrossRef] [PubMed]

10. Tzanakakis, V.A.; Paranychianakis, N.V. Divergent response of ammonia oxidizers to various amino acids. Appl. Soil Ecol. 2017, 114, 45-51. [CrossRef]

11. Ouyang, Y.; Norton, J.M.; Stark, J.M.; Reeve, J.R.; Habteselassie, M.Y. Ammonia-oxidizing bacteria are more responsive than archaea to nitrogen source in an agricultural soil. Soil Biol. Biochem. 2016, 96, 4-15. [CrossRef]

12. Yu, Z.; Zeng, D.; Jiang, F.; Zhao, Q. Responses of biomass to the addition of water, nitrogen and phosphorus in Keerqin sandy grassland, Inner Mongolia, China. For. Res. 2009, 20, 23-26. [CrossRef]

13. Wang, Z.; Zong, H.; Zheng, H.; Liu, G.; Chen, L.; Xing, B. Reduced nitrification and abundance of ammonia-oxidizing bacteria in acidic soil amended with biochar. Chemosphere. 2015, 138, 576-583. [CrossRef] [PubMed]

14. Abbasi, M.K.; Hina, M.; Tahir, M.M. Effect of Azadirachta indica (neem), sodium thiosulphate and calcium chloride on changes in nitrogen transformations and inhibition of nitrification in soil incubated under laboratory conditions. Chemosphere 2011, 82, 1629-1635. [CrossRef] [PubMed]

15. He, J.Z.; Shen, J.P.; Zhang, L.M.; Zhu, Y.G.; Zheng, Y.M.; Xu, M.G.; Di, H. Quantitative analyses of the abundance and composition of ammonia-oxidizing bacteria and ammonia-oxidizing archaea of a Chinese upland red soil under long-term fertilization practices. Environ. Microbiol. 2007, 9, 2364-2374. [CrossRef] [PubMed]

16. Wang, X.; Han, C.; Zhang, J.; Huang, Q.; Deng, H.; Deng, Y.; Zhong, W. Long-term fertilization effects on active ammonia oxidizers in an acidic upland soil in China. Soil Biol. Biochem. 2015, 84, 28-37. [CrossRef]

17. Segal, L.M.; Miller, D.N.; McGhee, R.P.; Loecke, T.D.; Cook, K.L.; Shapiro, C.A.; Drijber, R.A. Bacterial and archaeal ammonia oxidizers respond differently to long-term tillage and fertilizer management at a continuous maize site. Soil Tillage Res. 2017, 168, 110-117. [CrossRef]

18. Chu, H.; Fujii, T.; Morimoto, S.; Lin, X.; Yagi, K.; Hu, J.; Zhang, J. Community structure of ammonia-oxidizing bacteria under long-term application of mineral fertilizer and organic manure in a sandy loam soil. Appl. Environ. Microbiol. 2007, 73, 485-491. [CrossRef] [PubMed]

19. Wu, Y.; Lu, L.; Wang, B.; Lin, X.; Zhu, J.; Cai, Z.; Yan, X.; Jia, Z. Long-term field fertilization significantly alters community structure of ammonia-oxidizing bacteria rather than archaea in a paddy soil. Soil Sci. Soc. Am. J. 2011, 75, 1431-1439. [CrossRef]

20. Ai, C.; Liang, G.; Sun, J.; Wang, X.; He, P.; Zhou, W. Different roles of rhizosphere effect and long-term fertilization in the activity and community structure of ammonia oxidizers in a calcareous fluvo-aquic soil. Soil Biol. Biochem. 2013, 57, 30-42. [CrossRef]

21. Zheng, H.; Wang, Z.Y.; Deng, X.; Herbert, S.; Xing, B.S. Impacts of adding biochar on nitrogen retention and bioavailability in agricultural soil. Geoderma 2013, 206, 32-39. [CrossRef]

22. Zhang, X.; Tang, Y.; Shi, Y.; He, N.; Wen, X.; Yu, Q.; Zheng, C.; Sun, X.; Qiu, W. Responses of soil hydrolytic enzymes, ammoniaoxidizing bacteria and archaea to nitrogen applications in a temperate grassland in Inner Mongolia. Sci. Rep. 2016, 6, 32791. [CrossRef] [PubMed] 
23. Levicnik-Hofferle, S.; Nicol, G.W.; Ausec, L.; Mandic-Mulec, I.; Prosser, J.I. Stimulation of thaumarchaeal ammonia oxidation by ammonia derived from organic nitrogen but not added inorganic nitrogen. FEMS Microbiol. Ecol. 2012, 80, 114-123. [CrossRef] [PubMed]

24. Di, H.J.; Cameron, K.C. Nitrate leaching in temperate agroecosystems: Sources, factors and mitigating strategies. Nutr. Cycl. Agroecosyst. 2002, 64, 237-256. [CrossRef]

25. Cameron, K.C.; Di, H.J.; Moir, J.L. Nitrogen losses from the soil/plant system: A review. Ann. Appl. Biol. 2013, 162, 145-173. [CrossRef]

26. Guo, Y.J.; Di, H.J.; Cameron, K.C.; Li, B. Effect of application rate of a nitrification inhibitor, dicyandiamide (DCD), on nitrification rate, and ammonia-oxidizing bacteria and archaea growth in a grazed pasture soil: An incubation study. J. Soils Sediments 2014, 14, 897-903. [CrossRef]

27. Kleineidam, K.; Košmrlj, K.; Kublik, S.; Palmer, I.; Pfab, H.; Ruser, R.; Schloter, M. Influence of the nitrification inhibitor 3,4dimethylpyrazole phosphate (DMPP) on ammonia-oxidizing bacteria and archaea in rhizosphere and bulk soil. Chemosphere 2011, 84, 182-186. [CrossRef] [PubMed]

28. Qu, Z.; Wang, J.G.; Almøy, T.; Bakken, L.R. Excessive use of nitrogen in Chinese agriculture results in high $\mathrm{N}_{2} \mathrm{O} /\left(\mathrm{N}_{2} \mathrm{O}+\mathrm{N}_{2}\right)$ product ratio of denitrification, primarily due to acidification of the soils. Glob. Chang. Biol 2014, 20, 1685-1698. [CrossRef]

29. Tian, H.; Lu, C.; Ciais, P.; Michalak, A.M.; Canadell, J.G.; Saikawa, E.; Huntzinger, D.N.; Gurney, K.R.; Sitch, S.; Zhang, B. The terrestrial biosphere as a net source of greenhouse gases to the atmosphere. Nature 2016, 531, 225-228. [CrossRef]

30. Hangs, R.D.; Schoenau, J.J.; Lafond, G.; Breme, E. The effect of nitrogen fertilization and no-Till duration on soil nitrogen supply power and post-spring thaw greenhouse-Gas emissions. J. Plant Nutr. Soil Sci. 2013, 176, 227-237. [CrossRef]

31. Zhu, Z.L.; Chen, D.L. Nitrogen fertilizer use in China-Contributions to food production, impacts on the environment and best management strategies. Nutr. Cycl. Agroecosyst. 2002, 63, 117-127. [CrossRef]

32. Yang, S.M.; Malhi, S.S.; Song, J.R.; Xiong, Y.C.; Yue, W.Y.; Lu, L.L.; Wan, J.G.; Guo, T.W. Crop yield, nitrogen uptake and nitrate-Nitrogen accumulation in soil as affected by 23 annual applications of fertilizer and manure in the rainfed region of Northwestern China. Nutr. Cycl. Agroecosyst. 2006, 76, 81-94. [CrossRef]

33. Directive, C. Concerning the protection of waters against pollution caused by nitrates from agricultural sources. Off. J. 1991, 375, $1-8$.

34. Schröder, J.J.; Scholefield, D.; Cabralet, F.; Hofmanal, G. The effects of nutrient losses from agriculture on ground and surface water quality: The position of science in developing indicators for regulation. Environ. Sci. Policy 2004, 7, 15-23. [CrossRef]

35. Bai, Y.; Wu, J.; Clark, C.; Naeem, S.; Pan, Q.; Huang, J.; Zhang, L.; Han, X. Tradeoffs and thresholds in the effects of nitrogen addition on biodiversity and ecosystem functioning: Evidence from inner Mongolia Grasslands. Glob. Chang. Biol. 2010, 16, 358-372. [CrossRef]

36. Prosser, J.I.; Nicol, G.W. Archaeal and bacterial ammonia- oxidisers in soil: The quest for niche specialisation and differentiation. Trends Microbiol. 2012, 20, 523-531. [CrossRef]

37. Azziz, G.; Trasante, T.; Monza, J.; Irisarri, P. The effect of soil type, rice cultivar and water management on ammonia-oxidizing archaea and bacteria populations. Appl. Soil Ecol. 2016, 100, 8-17. [CrossRef]

38. Zhang, L.M.; Hu, H.W.; Shen, J.P.; He, J.Z. Ammonia-oxidizing archaea have more important role than ammonia-oxidizing bacteria in ammonia oxidation of strongly acidic soils. ISME J. Multidiscip. J. Microb. Ecol. 2012, 6, 1032-1045. [CrossRef] [PubMed]

39. Tsiknia, M.; Paranychianakis, N.V.; Varouchakis, E.A.; Nikolaidis, N.P. Environmental drivers of the distribution of nitrogen functional genes at a watershed scale. FEMS Microbiol. Ecol. 2015, 91, fiv052. [CrossRef] [PubMed]

40. Leininger, S.; Urich, T.; Schloter, M.; Schwark, L.; Qi, J.; Nicol, G.W.; Prosser, J.I.; Schuster, S.C.; Schleper, C. Archaea predominate among ammonia-oxidizing prokaryotes in soils. Nature 2006, 442, 806-809. [CrossRef] [PubMed]

41. O'Sullivan, C.A.; Wakelin, S.A.; Fillery, I.R.P.; Roper, M.M. Factors affecting ammonia-oxidising microorganisms and potential nitrification rates in southern Australian agricultural soils. Soil Res. 2013, 51, 240-252. [CrossRef]

42. Shen, J.P.; Zhang, L.M.; Zhu, Y.G.; Zhang, J.B.; He, J.Z. Abundance and composition of ammonia-oxidizing bacteria and ammonia-oxidizing archaea communities of an alkaline sandy loam. Environ. Microbiol. 2008, 10, 1601-1611. [CrossRef]

43. Jia, Z.; Conrad, R. Bacteria rather than Archaea dominate microbial ammonia oxidation in an agricultural soil. Environ. Microbiol. 2009, 11, 1658-1671. [CrossRef] [PubMed]

44. Tourna, M.; Freitag, T.E.; Nicol, G.W.; Prosser, J.I. Growth, activity and temperature responses of ammonia-oxidizing archaea and bacteria in soil N microcosms. Environ. Microbiol. 2008, 10, 1357-1364. [CrossRef] [PubMed]

45. Yang, L.; Zhu, G.; Liu, R. How nitrification related $\mathrm{N}_{2} \mathrm{O}$ is associated with soil ammonia oxidizers in two contrasting soils in China. Sci. Total Environ. 2020, 770, 143212. [CrossRef] [PubMed]

46. Tao, R.; Wakelin, S.A.; Liang, Y.; Chu, G. Response of ammonia-oxidizing archaea and bacteria in calcareous soil to mineral and organic fertilizer application and their relative contribution to nitrification. Soil Biol. Biochem. 2017, 114, 20-30. [CrossRef]

47. Yin, C.; Fan, F.L.; Song, A.L.; Fan, X.P.; Ding, H.; Ran, W.; Qiu, H.Z.; Liang, Y.C. The response patterns of community traits of N2O emission-related functional guilds to temperature across different arable soils under inorganic fertilization. Soil Biol. Biochem. 2017, 108, 65-77. [CrossRef]

48. Xu, A.; Li, L.; Xie, J.; Wang, X.; Coulter, J.A.; Liu, C.; Wang, L. Effect of Long-Term Nitrogen Addition on Wheat Yield, Nitrogen Use Efficiency, and Residual Soil Nitrate in a Semiarid Area of the Loess Plateau of China. Sustainability 2020, 12, 1735. [CrossRef] 
49. Food and Agriculture Organization. The State of Food and Agriculture; Food and Agriculture Organization of the United Nations: Rome, Italy, 1990.

50. Chinese Soil Taxonomy Cooperative Research Group. Chinese Soil Taxonomy (Revised Proposal); Institute of Soil Science, Chinese Agricultural Science and Technology Press: Beijing, China, 1995.

51. Bao, S.D. Analysis of Soil Agro-Chemistry; Agriculture Press: Beijing, China, 1999. (In Chinese)

52. National Agriculture Technology Extension and Service Center (NATESC). Soil Analysis Technology Specification; China Agriculture Press: Beijing, China, 2006; pp. 47-49. (In Chinese)

53. Li, X.; Deng, Y.; Li, Q.; Lu, C.; Wang, J.; Zhang, H.; Zhu, J.; Zhou, J.; He, Z. Shifts of functional gene representation in wheat rhizosphere microbial communities under elevated ozone. ISME J. 2013, 7, 660-671. [CrossRef]

54. O'Kelly, B.C. Accurate Determination of Moisture Content of Organic Soils Using the Oven Drying Method. Dry. Technol. 2004, 22, 1767-1776. [CrossRef]

55. Zhu, G.; Wang, S.; Feng, X.; Fan, G.; Jetten, M.; Yin, C. Anammox bacterial abundance, biodiversity and activity in a constructed wetland. Environ. Sci. Technol. 2011, 45, 9951-9958. [CrossRef]

56. Park, S.J.; Park, B.J.; Rhee, S.K. Comparative analysis of archaeal $16 \mathrm{~S}$ rRNA and amoA genes to estimate the abundance and diversity of ammonia-oxidizing archaea in marine sediments. Extremophiles 2008, 12, 605-615. [CrossRef]

57. Meinhardt, K.A.; Bertagnolli, A.; Pannu, M.W.; Strand, S.E.; Stahl, D.A. Evaluation of revised polymerase chain reaction primers for more inclusive quantification of ammonia-oxidizing archaea and bacteria: Revised primers for AOA and AOB quantification. Environ. Microbiol. Rep. 2015, 7, 1758-2229. [CrossRef] [PubMed]

58. Xiao, R.; Chen, B.; Liu, Y.; Wang, C.; Gu, J.; Feng, H.; Du, G.; Ma, X. Higher Abundance of Ammonia Oxidizing Archaea than Ammonia Oxidizing Bacteria and Their Communities in Tibetan Alpine Meadow Soils under Long-term Nitrogen Fertilization. Geomicrobiol. J. 2014, 31, 597-604. [CrossRef]

59. Wang, J.; Zhang, L.; Lu, Q.; Raza, W.; Huang, Q.; Shen, Q. Ammonia oxidizer abundance in paddy soil profile with different fertilizer regimes. Appl. Soil Ecol. 2014, 84, 38-44. [CrossRef]

60. Meyer, A.; Focks, A.; Radl, V.; Welzl, G.; Ingo, S.; Schloter, M. Influence of land use intensity on the diversity of ammonia oxidizing bacteria and archaea in soils from grassland ecosystems. Microb. Ecol. 2014, 67, 161-166. [CrossRef] [PubMed]

61. Okano, Y.; Hristova, K.R.; Leutenegger, C.M.; Jackson, L.E.; Denison, R.F.; Gebreyesus, B.; Lebauer, D.; Scow, K.M. Application of real-time PCR to study effects ofammonium on population size of ammonia-oxidizing bacteria in soil. Appl. Environ. Microbiol. 2004, 70, 1008-1016. [CrossRef] [PubMed]

62. Hermansson, A.; Lindgren, P.E. Quantification of ammonia oxidizing bacteria in arable soil by real-time PCR. Appl. Environ. Microbiol. 2001, 67, 972-976. [CrossRef] [PubMed]

63. Schauss, K.; Focks, A.; Leininger, S.; Kotzerke, A.; Heuer, H.; Thiele-Bruhn, W.; Sharma, B.; Matthies, M.; Smalla, K.; Munch, J.C.; et al. Dynamics and functional relevance of ammonia-oxidizing archaea in two agricultural soils. Environ. Microbiol. 2009, 11, 446-456. [CrossRef] [PubMed]

64. Zhou, Z.F.; Shi, X.J.; Zheng, Y.; Qin, Z.X.; Xie, D.T.; Li, Z.L.; Guo, T. Abundance and community composition of ammonia-oxidizing bacteria and archaea in purple soil under long-term fertilization. Eur. J. Soil Biol. 2014, 60, 24-33. [CrossRef]

65. Di, H.J.; Cameron, K.C.; Shen, J.P.; Winefield, C.S.; Callaghan, M.O.; Bowatte, S.; He, J.Z. Ammonia-oxidizing bacteria and archaea grow under contrasting soil nitrogen conditions. FEMS Microbiol. Ecol. 2010, 72, 386-394. [CrossRef] [PubMed]

66. Nicol, G.W.; Leininger, S.; Schleper, C.; Prosser, J.I. The influence of soil pH on the diversity abundance and transcriptional activity of ammonia oxidizing archaea and bacteria. Environ. Microbiol. 2008, 10, 2966-2978. [CrossRef]

67. Yang, Y.; Wang, Z.; Hu, Y.; Zeng, Z. Irrigation frequency alters the abundance and community structure of ammonia-oxidizing archaea and bacteria in a northern Chinese upland soil. Eur. J. Soil Biol. 2017, 83, 34-42. [CrossRef]

68. Wessén, E.; Nyberg, K.; Jansson, J.K.; Hallin, S. Responses of bacterial and archaeal ammonia oxidizers to soil organic and fertilizer amendments under long-term management. Appl. Soil Ecol. 2010, 45, 193-200. [CrossRef]

69. Akiyama, H.; Morimoto, S.; Hayatsu, M.; Hayakawa, A.; Sudo, S.; Yagi, K. Nitrification, ammonia-oxidizing communities, and $\mathrm{N} 2 \mathrm{O}$ and $\mathrm{CH} 4$ fluxes in an imperfectly drained agricultural field fertilized with coated urea with and without dicyandiamide. Biol. Fertil. Soils 2013, 49, 213-223. [CrossRef]

70. Xia, W.; Zhang, C.; Zeng, X.; Feng, Y.; Weng, J.; Lin, X.; Zhu, J.; Xiong, Z.; Xu, J.; Cai, Z. Autotrophic growth of nitrifying community in an agricultural soil. ISME J. 2011, 5, 1226-1236. [CrossRef] [PubMed]

71. Auguet, J.C.; Barberán, A.; Casamayor, E.O. Global ecological patterns in uncultured Archaea. ISME J. 2011, 4, 182-190. [CrossRef] [PubMed]

72. Bates, S.T.; Berg-Lyons, D.; Caporaso, J.G.; Walters, W.A.; Knight, R.; Fierer, N. Examining the global distribution of dominant archaeal populations in soil. ISME J. 2011, 5, 908-917. [CrossRef]

73. Fang, Y.; Wang, F.; Jia, X.; Chen, J. Distinct responses of ammonia-oxidizing bacteria and archaea to green manure combined with reduced chemical fertilizer in a paddy soil. J. Soils Sediments 2018, 19, 1613-1623. [CrossRef]

74. Duan, P.; Wu, Z.; Zhang, Q.; Fan, C.; Xiong, Z. Thermodynamic responses of ammonia-oxidizing archaea and bacteria explain $\mathrm{N}_{2} \mathrm{O}$ production from greenhouse vegetable soils. Soil Biol. Biochem. 2018, 120, 37-47. [CrossRef]

75. Xue, C.; Zhang, X.; Zhu, C.; Zhao, J.; Zhu, P.; Peng, C.; Ling, N.; Shen, Q.R. Quantitative and compositional responses of ammonia-oxidizing archaea and bacteria to long-term field fertilization. Sci. Rep. 2016, 6, 28981. [CrossRef] [PubMed] 
76. Song, H.; Che, Z.; Cao, W.; Huang, T.; Wang, J.; Dong, Z. Changing roles of ammonia-oxidizing bacteria and archaea in a continuously acidifying soil caused by over-fertilization with nitrogen. Environ. Sci. Pollut. Res. 2016, 23, 11964-11974. [CrossRef] [PubMed]

77. Chen, Y.L.; Xu, Z.W.; Hu, H.W.; Hu, Y.J.; Hao, Z.P.; Jiang, Y.; Chen, B.D. Responses of ammonia-oxidizing bacteria and archaea to nitrogen fertilization and precipitation increment in a typical temperate steppe in Inner Mongolia. Appl. Soil Ecol. 2013, 68, 36-45. [CrossRef]

78. Chen, X.; Zhang, L.M.; Shen, J.P.; Wei, W.X.; He, J.Z. Abundance and community structure of ammonia-oxidizing archaea and bacteria in an acid paddy soil. Biol. Fertil. Soils 2011, 47, 323-331. [CrossRef]

79. Ke, X.; Angel, R.; Lu, Y.; Conrad, R. Niche differentiation of ammonia oxidizers and nitrite oxidizers in rice paddy soil. Environ. Microbiol. 2013, 15, 2275-2292. [CrossRef] [PubMed]

80. Lentendu, G.; Wubet, T.; Chatzinotas, A.; Wilhelm, C.; Buscot, F.; Schlegel, M. Effects of long-term differential fertilization on eukaryotic microbial communities in an arable soil: A multiple barcoding approach. Mol. Ecol. 2014, 23, 3341-3355. [CrossRef]

81. Blanco-Canqui, H.; Ferguson, R.B.; Shapiro, C.A.; Drijber, R.A.; Walters, D.T. Does inorganic nitrogen fertilization improve soil aggregation? Insights from two long-term tillage experiments. J. Environ. Qual. 2014, 43, 995-1003. [CrossRef] [PubMed] 